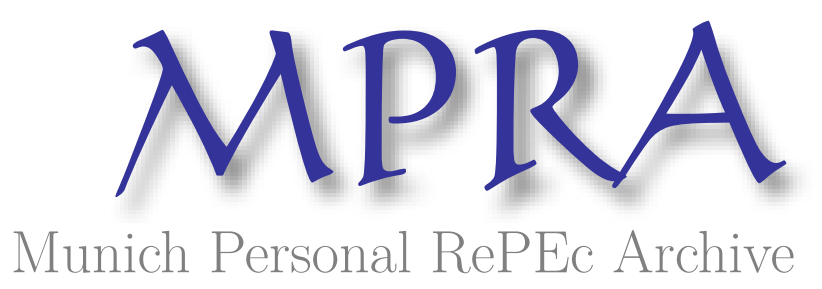

\title{
Distribution of Regional Income and Regional Funds in Europe 1989-1999: an Exploratory Spatial Data Analysis
}

Dall'erba, Sandy

2003

Online at https://mpra.ub.uni-muenchen.de/1378/

MPRA Paper No. 1378, posted 09 Jan 2007 UTC 


\title{
Distribution of Regional Income and Regional Funds in Europe 1989-1999: an Exploratory Spatial Data Analysis
}

\author{
Sandy Dall'erba ${ }^{1}$ \\ CATT, Université de Pau et des Pays de l'Adour (France) \\ and REAL, University of Illinois at Urbana Champaign (USA) \\ Centre d'Analyse Théorique et de Traitement des données économiques \\ Université de Pau et des Pays de l'Adour \\ Avenue du Doyen Poplawski \\ BP 1633, 64016 Pau Cédex, France \\ Phone : +33 559807531 \\ Fax : +33559408010 \\ (e-mail: sandy.dallerba@etud.univ-pau.fr)
}

\begin{abstract}
:
The efforts of the European Commission to reduce regional inequalities over its territory continues to attract the attention of researchers. The purpose of this paper is to perform an exploratory investigation of the relationship between the spatial distribution of regional income and of regional development funds among 145 European regions over 1989-1999. Using a set of tools of spatial statistics, we first detect the presence of global and local spatial autocorrelation in the distribution of regional per capita incomes, traducing that rich (poor) regions tend to be clustered close to other rich (poor) regions, and in the distribution of regional growth rate and regional funds. Second, the results of LISA statistics conclude to the presence of spatial heterogeneity in the form of two spatial clusters of rich and poor regions over the decade, highlighting the persistence of a significant core-periphery pattern among European regions. Finally, an exploratory analysis reveals a negative correlation between growth and initial income, that tends to indicate $\beta$-convergence. A positive relationship between regional growth and structural funds is identified among the significant results as well. Only Andalucia, Galicia and Sterea Ellada show atypical linkages. These results suggest that further research should include spatial effects and the distribution of regional funds in the spatial econometric estimation of regional convergence in Europe.
\end{abstract}

1 This paper has been written while I was a Fulbright Visiting-Researcher at the Regional Economics Applications Laboratory, University of Illinois at Urbana-Champaign (USA). I have benefited from useful comments of the participants of the $49^{\text {th }}$ Annual North American Meeting of the RSAI and the participants of the $42^{\text {nd }}$ Annual Meeting of the WRSA. I would like to thank most especially Julie Le Gallo, Phil Rees and two anonymous referees for their valuable suggestions. Financial support from the Région Aquitaine (France) is gratefully acknowledged. 


\section{Introduction}

The phenomenon of persistent income disparities among European regions has been widely studied in the literature, using $\beta$-convergence ${ }^{2}$ models, most of the time based on neoclassical specifications (Esteban, 1994; Neven and Gouyette, 1995). Together with $\sigma$ convergence, ${ }^{3}$ these concepts have been criticized for several econometric problems they bring about, like Galton's fallacy problem, and their inadequacy to explain economic polarization, persistent poverty and clustering (Quah, 1993). In contrast, the concepts of convergence clubs (Durlauf and Johnson, 1995; Chatterji, 1992; Quah, 1996) and coreperiphery (Krugman, 1991a, 1991b; Fujita et al., 1999) are compatible with the existence of multiple, locally stable steady state equilibria that are more relevant in the European regional case.

Another often-raised criticism comes from the fact that the majority of these empirical tests of regional income convergence are based on the same hypotheses as the ones underlying international income convergence: regions are considered as isolated entities, as if their geographical location and potential interregional linkages did not matter. Only recently, with the development of the appropriate tools of spatial statistics and spatial econometrics (Anselin, 1988, 2001; Anselin and Berra, 1998), has the role of spatial effects been considered in empirical works. These tools have been applied to regional convergence in the United-States (Rey and Montouri, 1999; Rey, 2001), in Europe (Fingleton, 1999 and 2001; Baumont et al., 2002; Bivand and Brunstad, 2002), in China (Ying, 2000), in Brazil (Magalhães et al., 2000), in Chile (Aroca et al., 2000) and Turkey (Gezici and Hewings, 2002). The underlying idea, based on economic geographic theories and growth theories, is that forces that are driving the relocation/agglomeration process and hence generating an even/uneven regional development may be attributed to such factors as productivity

\footnotetext{
$\beta$-convergence occurs when the poor regions tend to grow faster than the rich ones.

$\sigma$-convergence occurs when there is a reduction in the standard deviation of regional incomes.
} 
(Hirschman, 1958), transportation infrastructures (Krugman and Venables, 1995, 1996), technology and knowledge spillovers (Martin and Ottaviano, 1999), factor mobility (Krugman, 1991a, b; Puga, 1999), each of which has an explicit geographic component. Since geographic spillover effects influence the patterns of regional development, it is highly probable that these influences exhibit a non-random distinctive geographic pattern. Applied to the spatial distribution of income, evidence reveals that the rich (poor) regions have a propensity to be clustered close to other rich (poor) regions.

However, the European Commission considers regional imbalances unacceptable on distributional (spatial equity) and political grounds. The successive enlargements of the European Community to less developed countries have made regional disparities so prominent that $68 \%$ of structural funds are now devoted to the least developed regions (objective 1). Structural funds are the most important instruments of the European regional development policy with Ecu 154.5 billion (at 1994 prices) allocated over 1994-1999. However, their impact on regional development is not yet clear: most of the structural funds finance public infrastructures that are supposed to enhance cohesion among European regions (Aschauer, 1989). Many of these investments finance transportation infrastructures that result in a decrease in transportation costs, thereby potentially altering the locational attractiveness of regions. As a result, the benefits from these investments do not necessarily remain to benefit only the region in which they are implemented (Martin, 2000; Vickerman, 1996).

The purpose of this paper is to apply some newly developed techniques of spatial analysis to investigate the ability of the European Commission to favor cohesion through its regional policy. To this end, we perform an exploratory analysis of the relationship between the spatial distribution of per capita GDP and regional funds among 145 European regions over the period 1989-1999, a decade that corresponds to the first two programming periods in 
which European regional development policy was developed.. The paper proceeds as follows: section 2 describes the linkages between regional funds and even/uneven regional development. Section 3 presents the data. In section 4, we perform the exploratory spatial data analysis of the distribution of regional per capita GDP, of structural funds and of additional funds. The paper concludes with a summary and some closing remarks.

\section{Impact of structural funds on the spatial distribution of income}

European regional assistance over the 1989-1999 period dealt with six different objectives, the most important of which, with $68 \%$ of total structural funds devoted to this objective, was the objective 1, designed to address the economic development of the least prosperous regions. NUTS II level regions ${ }^{1}$ were eligible under this objective when their per capita GDP (in PPP, Purchasing Power Parity) was below $75 \%$ of the Community average. The other objectives were respectively devoted to the regions affected by industrial crisis (objective 2), by long-term unemployment (objective 3), the adaptation of the labor force (objective 4), agricultural structures (objectives 5a and 5b) and low density regions (objective 6). Objective 1 affected about 50 NUTS II level regions, and included the Mezzogiorno in Italy, all regions of Greece, Ireland and Portugal, and about two third of the Spanish regions. With regards to the type of projects financed, one third of structural funds (Ecu 77 billion at 1999 prices) were devoted to transportation infrastructures, while the rest supported human-capital enhancement and the productive sector directly. Transportation infrastructures have also been strongly supported through one half of the cohesion funds (Ecu 8 billion at 1999 prices), the second main instrument of regional policies, allocated since 1994 to Spain, Portugal, Greece and Ireland. They will not be formally included in the rest of the analysis since they

\footnotetext{
1 NUTS: Nomenclature of Territorial Units for Statistics. The Commission uses as regional statistical concept the spatial classification established by Eurostat on the basis of national administrative units. Europe can therefore be shared either in 77 NUTS I level regions, or 211 NUTS II, 1031 NUTS III, 1074 NUTS IV or 98433 NUTS V. Regional objectives are however mostly designated at either NUTS II or NUTS III level regions.
} 
are allocated at the national but not regional level, and since there are no data to reveal their regional distribution. For the European Commission, that has the goal of achieving the European Single Market, transportation infrastructures play a key role in the efforts to reduce the lack of cohesion among members.

However, from a theoretical as well as empirical point of view, their impact on regional development is not clear. On the one hand the endogenous growth models à la Aschauer (1989) and Barro (1990) predict that if public infrastructures are an input in the production function, then policies financing new public infrastructures increase the marginal product of private capital, fostering both capital accumulation and growth. On the other hand, the economic geography theoretical perspectives developed by Martin and Rogers (1995) and Martin (2000) demonstrate that when transportation infrastructures are financed, they affect the process of industry location and lead to involuntary effects. Financing intra-regional transport infrastructures in the poorest regions increases the probability of firms locating there, but reduces the country's aggregate growth rate and increases regional income inequalities. On the other hand, interregional transport infrastructures foster aggregate growth, but lead to greater concentration in the core. Moreover, an increasing part of the new transport infrastructures planed for the development of the trans-European network tend to be built within and between core regions, where transport demand is the highest (Vickerman, 1991, 1996). Only the regions that belong to the main network will gain in accessibility, whereas the regions that do not belong to it or are located at the edge of it will not.

The relationship between gain in accessibility and economic development in peripheral regions is not clear and requires further research, since it depends on the specific dependence on transport cost in each sector. There is no doubt that gains in accessibility due to interregional transport infrastructures will always be relatively higher in the core region than in the peripheral one (Vickerman et al., 1999; Venables and Gasiorek, 1999). Peripheral 
regions have generally lower unit costs than core regions and this advantage may attract activities to locate there. However, this attraction also depends on the level of transport infrastructure, the lack of which impedes the development of growth potential in the periphery, but the improvement of which does not necessarily promote its growth.

Three other points confirm that the allocation of regional funds does not necessarily promote regional development. First, a firm located in the targeted region does not necessarily undertake the construction of new infrastructures. As a result, a part of the value added of a project in one region may first benefit another location. Secondly, beyond this apparent desire to reduce interregional income inequalities, the EU aid is not necessarily correlated with the development gap or development potential. As pointed out by Fayolle and Lecuyer (2000), only objective 1 was devoted to the poorest regions. Objectives 2 and 3, even if they handle lower amounts, concern aid for industry restructuring that affect mostly regions that were formerly prosperous. Finally, a particular project is never implemented without additional regional or national financing. This is the principle of additionality that would preclude regions presenting dubious projects ${ }^{4}$. There is a bias introduced through this principle which comes from the fact that poor regions often have problems to match the European aid, whereas the aid can be tripled or quadrupled in regions with medium or high income levels, as they have more fiscal capacity to complement structural funds (Martin, 1998).

\section{Data}

The regional per capita GDP series in Ecu current prices come from the database New Cronos Regio by Eurostat. This is the official database used by the European Commission

\footnotetext{
4 Community funds support up to $75 \%$ of total public expenditure in NUTS regions, the rest depends on national or regional additionality in order to avoid regions present unviable projects. The ceilings vary according to the objective concerned: objective 1 finances a maximum $75 \%$ of the total cost, but $80 \%$ in cohesion countries (Spain, Portugal, Greece and Ireland) and $85 \%$ in the most remote regions and the outlying Greek islands. The other objectives financed a maximum $50 \%$ of the total cost.
} 
for its evaluation of regional convergence. We use the logarithms of the per capita GDP of each region over the 1989-1999 period in constant prices. Our sample is composed of 145 regions at NUTS II level (Nomenclature of Territorial Units for Statistics) over 12 EU countries:

- Belgium: 11 regions

- Denmark: 1 region

- Germany: 30 regions. Berlin and the nine former East German regions are excluded due to historical reasons

- Greece: 13 regions

- Spain: 16 regions, as we exclude the remote islands: Las Palmas, Santa Cruz de Tenerife Canary Islands and Ceuta y Mellila.

- France: 22 regions

- Ireland: 2 regions

- Italy: 20 regions

- Netherlands: 12 regions

- Portugal: 5 regions. The Azores and Madeira are excluded because of their geographical distance

- United Kingdom: 12 regions. In the case of the UK, we use regions at the NUTS I level, because NUTS II regions are not used as governmental units, they are merely statistical inventions of the EU Commission and the UK government.

- Luxembourg: 1 region

We do not include Austria, Finland and Sweden since they joined the EU only in 1995. The choice of studying European regions at the NUTS II level is purely based on regional development policies consideration. The data on structural funds come from the publications 
of the Commission. The period under study covers the two first programming periods: the data over 1989-1993 are from "Community structural interventions", Statistical report $n^{\circ} 3$ and 4,(July and Dec., 1992) $)^{5}$ and for 1994-1999, from The $11^{\text {th }}$ annual report on the structural funds. The data represent the total payments plus the total engagements of the European Commission at the date of publishing the $11^{\text {th }}$ report. Some of the funds were allocated to 6 German NUTS I regions and 2 Belgian NUTS I regions. We therefore disaggregate these funds at the NUTS II level with respect to their objective and their redistribution pattern ${ }^{6}$. With regard to the total cost of Community projects, we apply the same methodology and take also into account the fact that the richer NUTS 2 regions within the NUTS 1 region have more facility to accompany Community funds. This modification enables the bias introduced by additional funds to be considered in the formal analysis. Since these data are not annually available and we want to consider funds relatively to the local population, data are divided by the number of inhabitant (average over 1989-1999) for each region and expressed in constant prices. As we have seen in the previous section, structural funds are just a part of the financing of public infrastructures in lagging regions. Since national and regional co-financings also support Community investments, we will also consider the total cost of Community projects over the same period.

We are aware that our empirical results could be affected by missing regions and by the use of different levels of spatial aggregation. The choice of the spatial aggregation influences the magnitude of various measures of association. In the literature, this problem is referred to the modifiable areal unit problem (MAUP) (see Openshaw and Taylor, 1979), and also considered as an example of ecological fallacy (Anselin and Cho, 2000). Messner and Anselin (2001) add that scale is important as well. If the scale and spatial extent of units of observations for the data do not match up the scale and spatial extent of the studied process,

\footnotetext{
5 The author would like to thank Jacky Fayolle and Anne Lecuyer for providing this dataset.

6 The disaggregating methodology is available upon request.
} 
then it may result in a statistical problem wherein spatially correlated and/or heteroskedastic error structures occur. For instance, the area of Castilla-y-Leon (in Spain) is 585 times greater than the one of Brussels (Belgium), but both are official NUTS II regions (Casellas and Galley, 1999). Moreover, per capita growth in open formal NUTS 2 regions may reflect characteristics of neighboring regions. Boldrin and Canova (2001) discuss the problems linked to measuring a variable on a territorial unit that is artificially defined and in which people are free to move. They give the example of the city of Hamburg, a NUTS II level region with high per capita income, in which half the population of the whole Hamburg metropolitan area lives in the nearby NUTS II level regions of Schleswig-Holstein and Lower Saxony, commuting to Hamburg for work. As a result, the value added in Hamburg is overstated by $20 \%$ relative to its effective population, while those of Schleswig-Holstein (value added equals $102 \%$ of EU average) and Lower Saxony (104\%) are understated. This is similar for Ile de France (160\%) and Bassin Parisien (92.7\%), Communidad de Madrid (101\%) and its two neighboring Castillas (66 and 76\%).

\section{Exploratory spatial data analysis (ESDA)}

ESDA is a set of techniques used to describe and visualize spatial distributions, identify atypical locations or spatial outliers, discover patterns of spatial association, clusters or hot spots, and suggest spatial regimes or other forms of spatial heterogeneity (Anselin, 1988, 1999; Messner and Anselin, 2001; Haining, 1990)

\section{1- Mapping the distributions}

We start the analysis with the figure $1^{7}$. It is a choropleth map displaying the distribution of regional per capita GDP level in 1989 relative to the European average. A clear core-

\footnotetext{
7 All figures have been realized using ArcView GIS 3.2 (Esri).
} 
periphery pattern appears in this map, with the core (the darker color) composed of the richest regions, whereas the peripheral regions are also the poorest ones. Four different categories are presented. The first one includes the regions of Ireland, Portugal, Greece, the majority of the Spanish regions and six southern Italian ones with per capita GDP below $75 \%$ of the European average in 1989 (objective 1). The other categories show the distribution of regional income below the average but superior to $75 \%(75 \%-100 \%)$, higher than the average $(100 \%-150 \%)$ and strongly greater than the average $(>150 \%)$. Three regions had an exceptionally greater level of income than the overall distribution (greater than 1.5 interquartile ranges), thus are considered as outliers. These are the regions of Hamburg and Darmstadt in Germany, and Ile-de-France in France. These results are partly due to significant commuting from their neighboring regions, as was noted earlier for the case of Hamburg.

$<<$ insert figure 1 here $>>$

The core-periphery pattern in 1999 is still apparent and since there have been few changes, a separate figure is not included. Only the situation of the two Irish regions has clearly improved in comparison with the initial year. Actually the Irish per capita GDP has been greater than the EU average since 1997.

Figure 2 displays the distribution (in quartile) of the sum of structural funds on the average regional GDP over 1989-1999. As expected, the poor and peripheral regions are the ones that benefited the most from Community support. Note that two core regions (Hainaut in Belgium and Flevoland in Netherlands) belong to the most assisted regions as well. They even received more structural assistance than Attiki (Greece) or some Portuguese or Spanish regions. The explanation lies in the facts that the two regions received significant structural funds, but under objective 2 (for regions in industrial decline), whereas the poor Portuguese and Spanish regions received assistance only under objective 1. As explained in section 2, 
structural assistance is not only based on the objective of reducing income gaps. We do not perform an analysis of detecting outliers since the map makes clear that the poor and peripheral regions received exceptionally high levels of structural funds compared to the sample mean.

$<<$ insert figure 2 here $>>$

Figure 3 presents the ratio total project cost on structural funds (in quartile). The greater is this ratio, the greater is the regional or national co-financing in the total investment. In the poorest regions (first quartile), the total cost is until 2.2 times higher than the level of structural funds. It means that the region itself has to pay an amount equal to 1.2 times the level of structural funds. While peripheral regions are just able to double the Community support (first quartile), the wealthiest northern Spanish regions and numerous core regions succeed in providing from 2.5 to 6.4 times the amount committed by structural funds (upper quartile).

$$
<<\text { insert figure } 3 \text { here }>>
$$

The range of each category defined in the previous maps is rather large, and these maps do not allow reveal whether the spatial distribution of this variable is significantly persistent over the period. Moreover, they are also limited in the ability to identify any of the significant spatial effects that were introduced in the introduction.

\subsection{Determination of the spatial weight matrix}

Before going further in the spatial analysis of regional income distribution, some comments need to be made about the spatial weight matrix that will be employed in the analysis. In the European context, the presence of islands such as the United-Kingdom, Ireland or Corsica impedes adoption of simple contiguity matrices, since the weight matrix would include rows and columns with only zeros for these regions. Since unconnected observations are 
eliminated from the results of the global statistics, this would change the sample size and the interpretation of the statistical inference. Following the recommendations of Anselin (1996) and Anselin and Bera (1998), we choose to base them on pure geographical distance, as the exogeneity of geographical distance is unambiguous ${ }^{8}$. More precisely, we use the great circle distance between regional centroids. By using the great circle distance, dependence can be considered in any direction. Following Le Gallo and Ertur (2003), we base our weight matrices on the $k=10,15,20$ nearest neighbors. The form of the spatial weight matrix is the following:

$$
\left\{\begin{array}{l}
w_{i j}(k)=0 \text { if } i=j \\
w_{i j}(k)=1 \text { if } d_{i j} \leq D_{i}(k) \text { and }{ }^{*} w_{i j}(k)=w_{i j}(k) / \sum_{j} w_{i j}(k) \quad \text { for } k=10,15,20 \\
w_{i j}(k)=0 \text { if } d_{i j}>D_{i}(k)
\end{array}\right.
$$

where $d_{i j}$ is the great circle distance between centroids of region $i$ and $j . D_{i}(k)$ is the critical cut-off distance defined for each region $i$, above which interactions are assumed to be negligible. In other words, $D_{i}(k)$ is the $k^{\text {th }}$ order smallest distance between regions $i$ and $j$ such that each region $i$ has exactly $k$ neighbors. Each matrix is row standardized so that it is relative and not absolute distance that matters, yielding the matrix $w$. It is worth mentioning that in the European context, the minimum number of nearest neighbors that guarantees international connections between all regions is $k=7$, otherwise the Greek regions would not be linked to Italy at all. With $k=10$, Ireland is connected to the UK, which in turn is connected to the whole continent; and the islands of Sicilia, Sardegna, Corsica are connected

\footnotetext{
8 In the case of European regions, it could be attractive to base these weights on the channels of communication between regions, such as roads and railways (see Bodson and Peeters, 1975). However, as pointed out by Anselin and Bera (1998), "indicators for the socioeconomic weights should be chosen with great care to ensure their exogeneity, unless their endogeneity is considered explicitly in the model specification".
} 
to the continental French regions. When the number of $k$-nearest neighbors increases, the share of international interconnections increases as well.

\section{3- Moran' $I$}

We begin the analysis of the spatial distribution of regional income and regional funds by examining Moran's I statistics to capture the global spatial autocorrelation of the variables of interest. For each variable, the degree of linear association between its value at one location and the spatially weighted average of neighboring values is provided. We use a permutation approach with 10000 permutations (Anselin, 1995) ${ }^{9}$. Formally, for each variable of interest, the Moran's $I$ is given by:

$$
I_{t}=\frac{\sum_{i=1}^{n} \sum_{j=1}^{n}{ }^{*} w_{i j}(k) x_{i t} x_{j t}}{\sum_{i=1}^{n} \sum_{j=1}^{n} x_{i t} x_{j t}}
$$

where ${ }^{*}$ ij is the (row-standardized) degree of connection between the spatial units $i$ and $j$ and $x_{i t}$ is the variable of interest in region $i$ at year $t$ (measured as a deviation from the mean value for that year). Values of $I$ larger (smaller) than the expected value $E(I)=-1 /(n-1)$ indicate positive (negative) spatial autocorrelation. In our case, $E(I)=-0.00694$.

$$
<<\text { insert table } 1 \text { here }>>
$$

The results in table 1 report the value of Moran's $I$ and of the standard deviation for all the variables. ${ }^{10}$ Moran's $I$ statistics are positive and significant $(p$-value $=0.0001)$ for all variables. For the regional per capita income, it means that the rich (poor) regions have a

\footnotetext{
9 We use the SpaceStat 1.91 software to realize all the computations (Anselin, 1999).

10 The results are similar to those found with the Geary's c statistics. Complete results are available upon request.
} 
propensity to be clustered close to other rich (poor) regions. We note that the values of the statistics seem stable over the period, but they are higher over the 1993-1995 period, one that corresponds to greater integration after the 1992 Maastricht Treaty. The distribution of the regional per capita GDP in Europe is therefore certainly not random. With the same idea, objective (non-objective) regions, i.e. regions with high (low) structural funds, have a propensity to be close to other objective (non-objective) regions. The extent of Moran's $I$ statistics reveals a higher clustering of regions with similar structural funds than with similar Community projects, for all weight matrices. Differences among values of Community projects seem smaller than among structural funds according to the standard deviation as well. One explanation is that the last ones have structural purposes, therefore their amount and location are targeted. On the contrary, the first ones depend more on national/regional contributions that easily complement Community support in the rich regions. Results also display a clustering of regions with high (slow) growth rates. The Moran's $I$ can detect global spatial autocorrelation, but it is not able to identify local patterns of spatial association, such as local spatial clusters or local spatial outliers of high (low) values that are statistically significant. Identifying the groups of regions belonging to clustering of high (low) values of per capita income is based on the results of a Moran scatterplot.

\subsection{Moran's scatterplot}

The idea of the Moran scatterplot, suggested by Anselin (1996), is to display the per capita income for each region (on the horizontal axis) against the standardized spatial weighted average (average of the neighbors' per capita income, also called spatial lag) on the vertical axis. As pointed out by Anselin (1999), expressing the variables in standardized form (i.e. with mean zero and standard deviation equal to one) allows assessment of both the global spatial association, since the slope of the line is the Moran's $I$ coefficient, and local spatial 
association (the quadrant in the scatterplot). The Moran scatterplot is therefore divided into four different quadrants corresponding to the four types of local spatial association between a region and its neighbors:

- quadrant I (on the top right corner) displays the regions with a high per capita income (above the average) surrounded by regions with high per capita income (above the average). This quadrant is usually noted $\mathrm{HH}$.

- quadrant II (on the top left corner) shows the regions with low value surrounded by regions with high values. This quadrant is usually noted $\mathrm{LH}$.

- quadrant III (on the bottom left) displays the regions with low value surrounded by regions with low values, and is noted LL.

- quadrant IV (on the bottom right) shows the regions with high value surrounded by regions with low values. It is noted HL.

Regions located in quadrants I and III refer to positive spatial autocorrelation, the spatial clustering of similar values, whereas quadrants II and IV represent negative spatial autocorrelation, the spatial clustering of dissimilar values.

$$
<<\text { insert figure } 4>>
$$

Figure 4 displays the Moran scatterplots of regional per capita GDP for 1989, with $k=10$ nearest neighbors. Positive spatial autocorrelation, detected by the value of Moran's I, is reflected by the fact that most of the regions are located in quadrant I and III. Compared to the situation in the final period ${ }^{11}$, most of the regions that belong to quadrant I (III) in 1989 also belong to quadrant I (III) in 1999. However, there are some exceptions such as the two Irish regions that were LL at the initial year and are $\mathrm{HH}$ (Dublin) or LH (Border) at the final year. This reflects the rapid development of Ireland over the decade. Other signs of

11 Complete results available upon request. 
development concern three Belgian regions (Luxembourg, Brabant-Wallon, Antwerpen) and Yorkshire and the Humber (UK) which go from LH-type to HH-type.

On the contrary, signs of decline may be seen in one Italian region (Abruzzo) that moves from HH-type to LL-type, Picardie (France), Trier and Lüneburg (Germany) and Drenthe (Netherlands) that move from HH- to LH-type. The Moran scatterplot also enables identification of regions with higher spatial instability for both years (HL-type and LH-type): Aquitaine in France (HL), whereas Corse, Languedoc-Roussillon, Limousin (France), Wales, North-East (UK), Namur, Hainaut (Belgium), Flevoland and Friesland (Netherlands) are LHtype. This implies that the spatial distribution of regional income is more complicated that the simple core-periphery framework previously noticed in the choropleth maps. Le Gallo and Ertur (2003) reached the same conclusions for 138 European regions over 1980-1995.

The same method is applied to structural funds and Community projects total costs as well. The results for structural funds are presented in figure 5. Here again, most of the regions are located in quadrants I and III. Regions in I (III) are basically the regions that were in III (I) in figure 4, reflecting the efforts at promoting cohesion by the Commission. However, the regions Madrid (Spain), Norte and Lisboa and Vale do Tejo (Portugal) were LL-type for their income in 1989 and 1999, but are LH for both structural funds and Community funds because they are among the richest of the Iberian Peninsula. The region of Dublin in Ireland is by far the first beneficiary of the allocation of structural funds and Community projects (it is not displayed in the figure). To a lesser extent, this is also true for the Greek region Voreio Aigaio and the Spanish Extremadura.

$$
<<\text { insert figure } 5>>
$$

The last three columns of table 2 present the scatterplot quadrants for total structural funds over the average income 89-99, Community projects total costs over the average income 8999 and additional funds. The results for additional funds confirm that the rich regions are 
more able to complement structural funds whereas the poor ones cannot. In Spain for instance, the regions of Navarra, La Rioja and Cataluña have signifiant additions to the Community funds, which may be a reason for increasing disparities among Spanish regions (Fayolle and Lecuyer, 2000).

$<<$ insert table $2>>$

\subsection{LISA (Local Indicator of Spatial Association)}

The previous scatterplots display a slight modification of the overall structure of spatial autocorrelation between the initial and the final year. For instance, some regions that were $\mathrm{HH}$ in the initial year belong to another quadrant in the final year. We therefore calculate LISA statistics for each observation to obtain an indication of the extent to which there has been significant spatial clustering of similar values around that observation. Moreover, the sum of LISAs for all observations is proportional to a global indicator of spatial association (Anselin, 1995). Since we use a row-standardized matrix, the average of local Moran statistics is equal to the global Moran's $I$ statistics. LISA statistics are used for the detection of significant local spatial clusters (also called "hot spots") as well as for the diagnostics of local instability, significant outliers and spatial regimes. Anselin (1995) formalized the local Moran's statistics for each region $i$ and year $t$ in the following way:

$$
I_{i t}=\left(\frac{x_{i t}}{m_{0}}\right) \sum_{j}^{*} w_{i j} x_{j t} \quad \text { with } m_{0}=\sum_{i} x_{i t}^{2} / n
$$

with $x_{i t}\left(x_{j t}\right)$ is the observation in region $i(j)$ at year $t$ (measured as a deviation from the mean value for that year). The results from the application of LISA with $k=10$ nearest neighbors are summarized in columns three to seven of table 2. The robustness of these results is revealed in tables 3 and 4 with $k=15$ and 20 neighbors respectively. The significance level is based on a conditional permutation approach with 10000 random 
permutations of the neighboring regions for each observation (Anselin, 1995). The pseudosignificance level is $5 \%$. However, due to a problem of multiple statistical comparisons, since the neighborhood sets of two regions may contain common regions (Ord and Getis 1995; Anselin, 1995), we follow the methodology of Le Gallo and Ertur (2003) and present also in column 8 the number of years for which the results are significant at a 5\% Bonferroni pseudo-significance level ( $=5 \%$ over 10 since we use the 10 nearest-neighbors).

In columns three to seven of table 2, each cell displays the number of years the significant local Moran statistics is located in a particular Moran scatterplot quadrant. The regions revealing significant and greater spatial association of per capita GDP (HH or LL) are basically those previously detected as core (HH cluster) and peripheral (LL cluster) regions. Over the period, $97 \%$ of the local statistics that are significant are either HH- or LL-type, reflecting the global trend of positive spatial association. However, not all core/peripheral regions cluster significantly over the period. Local Moran statistics are not significant over the period for various regions in different countries (column 3 in table 2). Denmark, Greece and Portugal are the only countries without any non-significant statistics throughout the period (in Germany, Düsseldorf is the only region displaying non-significant statistics). Regions displaying positive local spatial association throughout the 11 years can be identified as follows:

- two different HH-type clusters can be identified because they are distant from each other:

- all the German regions (but Düsseldorf), Denmark, four northern French regions (Nord-Pas-de-Calais, Lorraine, Alsace, Franche-Comté), four southern Belgian regions (Antwerpen, Luxembourg, Limburg and Vlaams-Brabant), and four southern Dutch regions (Zuid-Holland, Zeeland, Noord-Brabant and Limburg).

- six Italian regions (Piemonte, Valle d'Aosta, Lombardia, Trentino-Alto Adige, Veneto and Friuli-Venezia Giulia). 
- two different LL-type clusters can also be identified for the same reason :

- all the Portuguese regions and eleven Spanish regions (Galicia, Asturias, Cantabria, Madrid, Castilla-y-Léon, Castilla-la-Mancha, Extremadura, Communidad Valenciana, Baléares, Andalucia and Murcia)

- all the Greek regions and four southern Italian regions (Puglia, Basilicata, Calabria, Sicilia).

All of them show positive spatial autocorrelation with a significance level $p<0.05$ for more than 5 years. The persistence of different clusters of high and low income is a sign of spatial heterogeneity among European regions confirming the persistence of income disparities. These results are robust when we use $k=15$ or 20 neighbors, confirmed by the robustness analysis for LISA (suggested by Le Gallo and Ertur, 2003) displayed in tables 3 and 4. Significant negative spatial autocorrelation occurs over 10 years for the French region of Corsica (LH-type), but no more than three years elsewhere. Two interpretations can be noted from these tables. First, when we increase the number of neighbors, a region with a significant LISA remains in the same quadrant. Secondly, respectively $21.9 \%$ and $31.6 \%$ of the regions with non significant LISA for $k=10$ become HH-type when $k=15$ and $k=20$. These regions are mostly French, North-Italian, Belgian, Dutch and British, whereas the regions becoming LL-type (4.6\% when $k=15$ and $4.5 \%$ when $k=20)$ are mostly Spanish and Southern Italian.

$<<$ insert tables 3 and 4 here $>>$

If we focus now on the column giving the significant Moran scatterplot quadrants for growth over 1989-1999, the significant HH-type correlation applies to all the Portuguese and Irish regions, the Greek regions (except Ipeiros and Sterea Ellada), only Extremadura in Spain and five British regions. Only three regions have a significant Moran statistic in Spain, which can be explained by the fact that Spain is the country where regional inequities have increased the 
most over this period. The LL-growth-type regions are Italian (except Calabria and Puglia), ten French regions, mostly in the South, six German regions (Tübingen, Freiburg, Karlsruhe, Rheinhessen-Pflaz, Darmstadt and Arnsberg) and Baleares in Spain. Six regions show significant negative spatial autocorrelation: Andalucia and Galicia in Spain, Sterea Ellada in Greece are LH-type, which indicates that they failed to develop in spite of the dynamism of their neighboring regions. On the other hand, three HL-type regions (Corse in France, Gießen and Kassel in Germany) show a significantly higher dynamism than their neighbors.

\section{$<<$ insert table 5 here $>>$}

Table 5 is a correlation table between the initial per capita income and the growth rate over the period. Only $27 \%$ of the results are significant for both initial per capita income and growth rate. However, it is interesting to note that $82 \%$ of these results show an inverse relationship between initial conditions and growth rates. The five Portuguese regions, nine out of thirteen Greek regions (the others do not have significant results) and Extremadura in Spain were LL-type for their initial income, but were HH-type for their growth rate over 1989-1999. Among the significant results, the conditions of $\beta$-convergence seem respected since the poor regions also have the highest growth rates. The Irish and Spanish regions do not appear here since the results for initial income are not significant in Ireland, and most of the results for growth are not significant in Spain. On the contrary, the regions displaying significant HH-type for the initial income and significant LL-type for growth are six German regions (Karlsruhe, Freiburg, Tübingen, Darmstadt, Arnsberg, Rheinhessen-Pflaz), three French regions (Alsace, Franche-Comté, Provence-Alpes-Cote-d'Azur), nine northern Italian regions (Piemonte, Valle d'Aosta, Liguria, Lombardia, Trentino-Alto Adige, Veneto, FriuliVenezia Giula, Emilio-Romagna). Three regions, Gießen and Kassel in Germany and Corse in France (but only in 1989) were HH-type for the initial income and HL-type for growth. The two German regions have therefore succeeded in growing faster than their neighbors, in 
spite of a high initial level of income, like their neighbors. Three regions (Galicia and Andalucia in Spain and Sterea Ellada in Greece) are significantly LL-type for their initial income but LH-type for their growth. It means that even if these regions started with the same initial conditions as their neighbors, their neighbors performed better in terms of development.

Instead of describing the significant results for LISA statistics on regional funds presented in the last three columns of table 2, the last step of our analysis will focus directly on the correlation between structural funds (then additional funds) and regional growth presented in table 6 .

$<<$ insert table 6 here $>>$

Only $28 \%$ of the results are significant for both structural funds and growth. However, $78 \%$ of these results show a positive relationship between growth and structural funds. Fourteen regions characterized by significant $\mathrm{HH}$-type structural funds show significant $\mathrm{HH}$-type growth. These regions are nine Greek regions (see table 2), Dublin in Ireland, three Portuguese regions (Centro, Alentejo and Algarve) and Northern Ireland (UK). On the contrary, the regions with LL-type growth and LL-type structural funds are six German regions (Karlsruhe, Freiburg, Tübingen, Damrstadt, Arnsberg, Rheinhessen-Pflaz), five French regions (Alsace, Franche-Comté, Poitou-Chatentes, Limousin, Auvergne), six Italian regions (Piemonte, Valle d'Aosta, Lombardia, Trentino-Alo Adige, Veneto, Fruili Veneza Giulia) and Luxembourg (country).

The atypical patterns of growth-structural funds relationships for regions with a different development behavior than their neighbors, in spite of the fact that they all are "similarly" assisted. $^{12}$ For instance, Gießen and Kassel (Germany) are LL-type for structural funds, but HL-type for growth. They performed better than their neighbors, in spite of a similar low

12 We put this word into quotation marks because the per capita levels of regional assistance may be very different, even if they belong to the same quadrant in the Moran scatterplot. 
level of structural funds. Norte and Liboa e Vale do Tejo in Portugal and Scotland (UK) are also insightful since they are HH-type growth but LH-type structural funds. On the contrary, Galicia, Andalucia (Spain) and Sterea Ellada (Greece) do not grow as fast as their neighbors, even if they received "similar" structural assistance (LH growth, HH funds).

Clearly, structural funds are not the main variable driving even/uneven regional development. A closer look at the economic structure, the accessibility, the institutional aspects of each region as well as the type of projects that structural funds finance in these regions and their neighboring regions could help explain why these regions display greater/smaller development progress than their neighbors even if they receive similar amount of structural funds.

Further, the perpetuation of disparities may be attributed in part to a region's ability to provide additional, matching funds. Again, the correlation displays that regions with low additional funds (the poor ones since they cannot afford additional investment) have a $\mathrm{HH}$ type growth and inversely ${ }^{13}$. An interesting case is for the three regions that display significant LH-type for growth and LL-type for additional funds: Sterea Ellada in Greece, Andalucia and Galicia in Spain. Remember that these regions are HH-type for structural funds. Therefore, if they do not perform as well as at their neighbors in terms of development, the reason does not come from higher additional funds in neighboring regions. Once again, a closer look at the specific economic structure of these regions as well as the use of regional funds could help to clarify the presence of "atypical" linkages between growth and structural funds detected in table 6.

13 Complete results upon request. 


\section{Conclusion}

The aim of this paper has been to perform an exploratory analysis of the ability of the European Commission to reduce regional disparities through its regional policy. We have investigated relationships between the spatial distribution of per capita GDP and of regional funds of 145 European regions over 1989-1999, using an exploratory spatial data analysis. This period corresponds to the two first program periods wherein regional assistance to the poorest regions was made available. We first used Moran's I to detect the presence of positive global spatial autocorrelation in the distribution of per capita GDP to explore whether the rich (poor) regions have a propensity to be clustered close to other rich (poor) regions. Global spatial autocorrelation also characterizes the regional growth rate, structural funds and Community projects total costs. Further analysis using Moran's scatterplot reveals also the presence of positive local spatial autocorrelation for each of the previous variables.

When LISA is performed, the results confirm the significant presence and persistence over time of local spatial autocorrelation in the form of two distinct spatial clusters of high and low values of per capita income. This form of spatial heterogeneity reflects a core-periphery pattern since per capita GDP inequalities are persistent among European regions. LISA is also performed on the spatial distribution of the regional growth rate. When an exploratory investigation of the correlation between the spatial patterns of the variables is performed, a negative relationship between regional growth and initial income level is detected among the significant results, a finding that seems consistent with the hypothesis of $\beta$-convergence. A positive relationship between regional growth and structural funds is also identified among the significant results. It may reflect the distributional efforts of the European Commission that has devoted the most important part of its funds to help the least developed regions and therefore provides little assistance to the rich regions. However, the results also indicate that structural funds are clearly not the only variable to control for the various growth rates among 
European regions. This is confirmed by the presence of "atypical" linkages between both variables in Andalucia, Galicia and Sterea Ellada. These results show that studies of European regional development should take into account the level of structural funds devoted to the objective region itself, but also to its neighboring regions. However, given the exploratory nature of our analysis, this paper calls for a thorough mutli-regional estimation of the workings of the system involved. In the absence of interregional input-output tables in Europe, this could be done, for example, using a spatial econometric estimation where spatial effects, initial conditions and the spatial distribution of both structural funds and Community projects total costs would be included in the estimation of the European regional convergence process. While this need is important for a better understanding of the impact of regional funds on cohesion, this is beyond the scope of this paper. 


\section{References}

Anselin L. (1988) Spatial Econometrics: Methods and Models. Dordrecht: Kluwer Academic Publishers.

Anselin, L. (1995) Local Indicator of Spatial Association-LISA. Geographical Analysis 27:93-115.

Anselin L. (1996) The Moran Scatterplot as an ESDA Tool to Assess Local Instability in Spatial Association, in Fisher M., Scholten H.J., Unwin D. (Eds), Spatial Analytical Perspectives on GIS in Environmental and Socio-Economic Sciences, 111-125, London: Taylor and Francis.

Anselin L. (1999) Interactive Techniques and Exploratory Spatial Data Analysis, in Geographic Information System: Principles, Techniques, Management and Applications, Longley P.A., Goodchild M.F., Maguire D.J. and Rhind D.W. (Eds.), New York: John Wiley.

Anselin L. (2001) Spatial Data Analysis, Laboratory Exercises. Prepared for the Workshop in Spatial Analysis, Wharton Schoold, University of Pennsylvania, August 29-31, 2001.

Anselin L. and Bera A. (1998) Spatial Dependence in Linear Regression Models with an Introduction to Spatial Econometrics, in Ullah A. and Giles DEA (Eds.), Handbook of Applied Economic Statistics. Berlin, Springer-Verlag.

Anselin L. and Cho W.K.T. (2000) Spatial Effects and Ecological Inference. Political Analysis 10:276-297.

Aroca P., Bosch M. and Hewings G.J.D. (2000) Regional Growth and Convergence in Chile 1960-1998: the Role of Public and Foreign Direct Investment. Working Paper of IDEAR, Universidad Catolica del Norte.

Aschauer D. (1989) Is Public Infrastructure Productive? Journal of Monetary Economics 23:177-200.

Barro R. J. (1990) Government Spending in a Simple Model of Endogenous Growth. Journal of Political Economy 98:103-125.

Baumont C., Ertur C. and Le Gallo J. (2003) Spatial Convergence Clubs and the European Growth Process, 1980-1995, in Fingleton B. (Ed.), European Regional Growth, Berlin: Springer, 131-158.

Bivand R.S. and Brunstad R.J. (2002) Regional Growth in Western Europe: an Empirical Exploration of Interactions with Agriculture and Agricultural Policy. Discussion Paper 01/02, Norwegian School of Economics and Business Administration.

Bodson P. and D. Peeters (1975) Estimations of the Coefficients in a Linear Regression in the Presence of Spatial Autocorrelation: An Application to a Belgian Labour-Demand Function. Environment and Planning A 7:455-72.

Boldrin M. and Canova F. (2001) Europe's Regions, Income Disparities and Regional Policies. Economic Policy 32:207-253.

Casellas A. and Galley C. (1999) Regional Definitions in the European Union: A question of Disparities? Regional Studies 33:551-558.

Chatterji M. (1992) Convergence Clubs and Endogenous Growth. Oxford Review of Economic Policy 8:57-69.

Durlauf S.N. and Johnson P.A. (1995) Multiple Regimes and Cross-Country Growth Behaviour. Journal of Applied Econometrics 10:365-384.

European Commission (1992) Community Structural Interventions. Statistical report $n^{\circ} 3$, July. 
European Commission (1992) Community Structural Interventions. Statistical report $\mathrm{n}^{\circ} 4$, December.

European Commission (1999) $11^{\text {th }}$ Annual Report on the Structural Funds. Commission Report.

Fayolle J. and Lecuyer A. (2000) Croissance Régionale, Appartenance Nationale et Fonds Structurels Européens, un Bilan d'Etape. Revue de l'OFCE 73:165-196.

Fingleton B. (1999) Estimates of Time to Economic Convergence: an Analysis of Regions of the European Union International Regional Science Review 22:5-34.

Fingleton B. (2001) Equilibrium and Economic Growth: Spatial Econometric Models and simulations Journal of Regional Science 41:117-147.

Fujita M., Krugman P. and Venables A.J. (1999) The Spatial Economy, Cambridge, MIT Press.

Gezici F. and Hewings G.J.D. (2002) Regional Convergence and the Economic Performances of Peripheral Areas in Turkey. Discussion Paper 01-T-13, Regional Economics Applications Laboratory, University of Illinois, Urbana.

Haining R. (1990) Spatial Data Analysis in the Social and Environmental Sciences. Cambridge: Cambridge University Press.

Hirschman A.O. (1958) The Strategy of Development, Yale University Press, New Haven (Conn).

Krugman P. (1991a) Geography and Trade, Cambridge MA, the MIT Press.

Krugman P. (1991b) Increasing Returns and Economic Geography. Journal of Political Economy 99:483-499.

Krugman P., Venables A. (1995) Globalization and the Inequality of nations. Quarterly Journal of Economics 110:715-756.

Krugman P., Venables A. (1996) Integration, Specialization, and Adjustment. European Economic Review 40:959-967.

Le Gallo J. and Ertur C. (2003) Exploratory Spatial Data Analysis of the distribution of regional per capita GDP in Europe, 1980-1995, Papers in Regional Science, 82:175-201.

Magalhães A., Hewings G.J.D., Azzoni C.R. (2000) Spatial Dependence and Regional Convergence in Brazil. Discussion Paper 00-T-11, Regional Economics Applications Laboratory, University of Illinois, Urbana.

Martin P. (2000) The Role of Public Policy in the Process of Regional Convergence. EIB Papers 5 (2):69-79.

Martin P. and Ottaviano G.I.P.(1999) Growing Locations: Industry Location in a Model of Endogenous Growth. European Economic Review 43:281-302.

Martin P. and Rogers C.A. (1995) Industrial Location and Public Infrastructure. Journal of International Economics 39:335-351.

Martin R. (1998) Regional Incentive Spending for European Regions. Regional Studies 32:527-536.

Messner S.F. and Anselin L. (2001) Spatial Analyses of Homicide with Areal Data. Unpublished document.

Openshaw S. and Taylor P. (1979) A Million or so Correlation Coefficient: Three Experiments on the Modifiable Areal Unit Problem, in Wrigley N. (Eds.), Statistical Applications in the Spatial Science, Pion: London.

Puga D. (1999) The Rise and Fall of Regional Inequalities. European Economic Review 43:303-334.

Quah D. (1993) Galton's Fallacy and Tests of the Convergence Hypothesis. Scandinavian Journal of Economics 95:427-443.

Quah D. (1996) Regional Convergence Clusters across Europe. European Economic Review 40:1951-1958. 
Rey S.J. and Montouri B.D. (1999) US Regional Income Convergence: A Spatial Econometric Perspective. Regional Studies 33:143-156.

Rey S. (2001) Spatial Empirics for Economic Growth and Convergence. Geographical Analysis 33:194-214.

Venables A. and Gasiorek M. (1999) Evaluating Regional Infrastructure: a Computable Equilibrium Approach. Study of the Socio-economic Impact of the Projects Financed by the Cohesion Fund - A Modelling Approach, vol. 2. Luxembourg: Office for Official Publications of the European Communities.

Vickerman R.W. (1991) Infrastructure and Regional Development, Pion, London.

Vickerman R.W. (1996) Location, Accessibility and Regional Development: the Appraisal of Trans-European Networks. Transport Policy 2:225-234.

Vickerman R., Spiekermann K. and Wegner M. (1999) Accessibility and Economic Development in Europe. Regional Studies 33:1-15.

Ying L.G. (2000) Measuring the Spillover Effects: Some Chinese Evidence. Papers in Regional Science 79:75-89. 


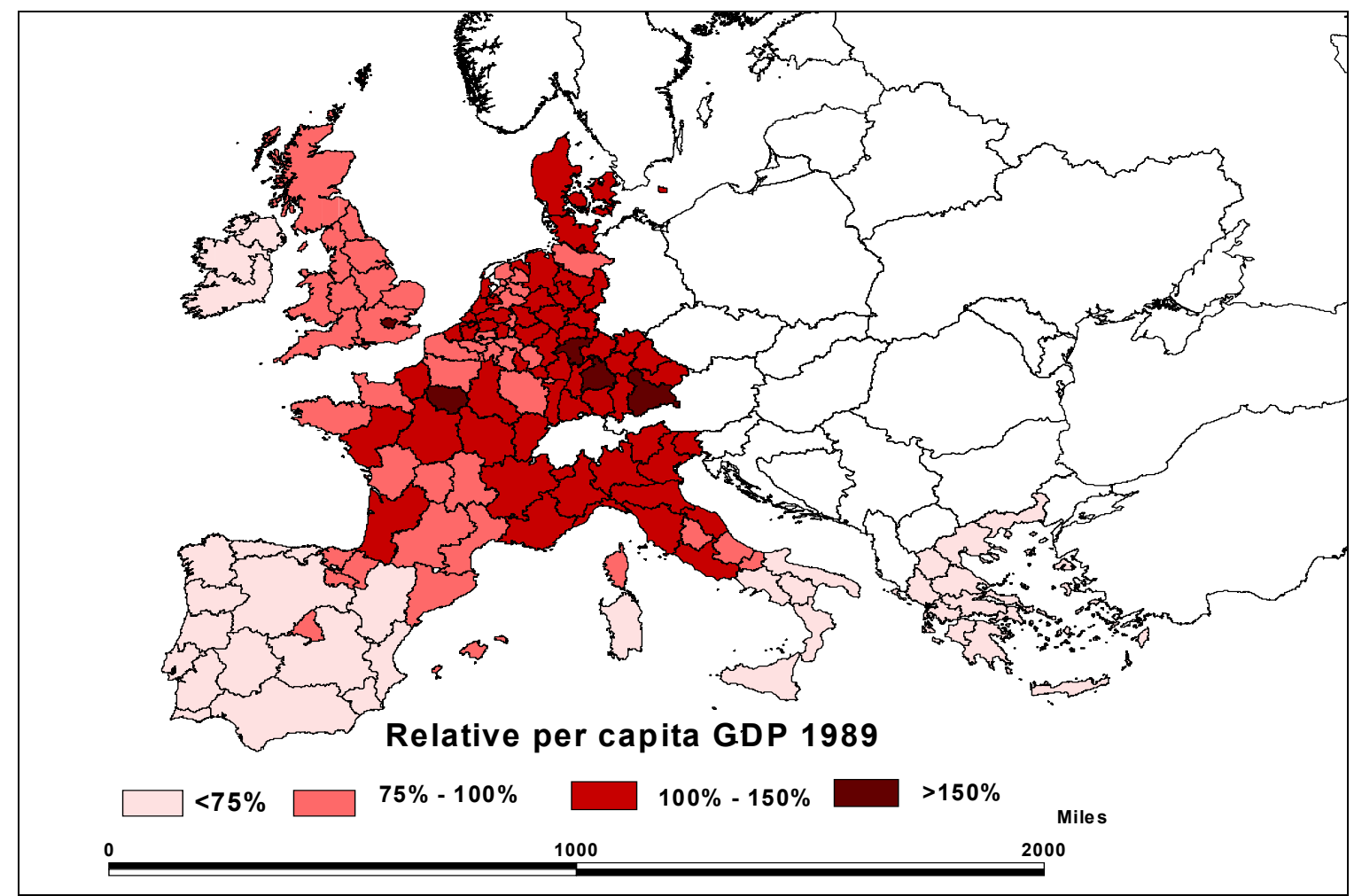

Figure 1: Spatial distribution of regional per capita GDP relative to the European average in 1989

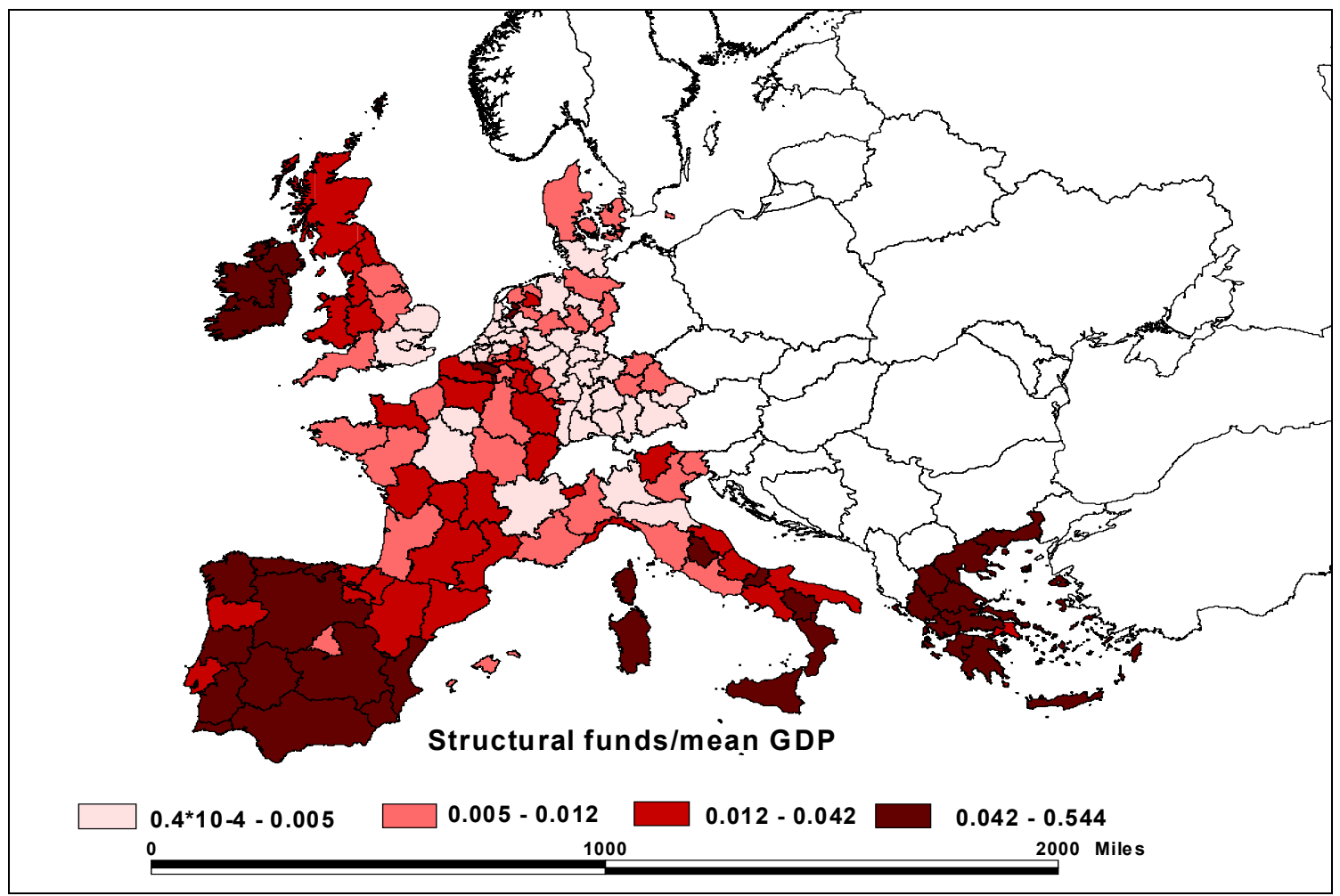

Figure 2: Structural funds divided by the mean regional GDP 1989-1999 


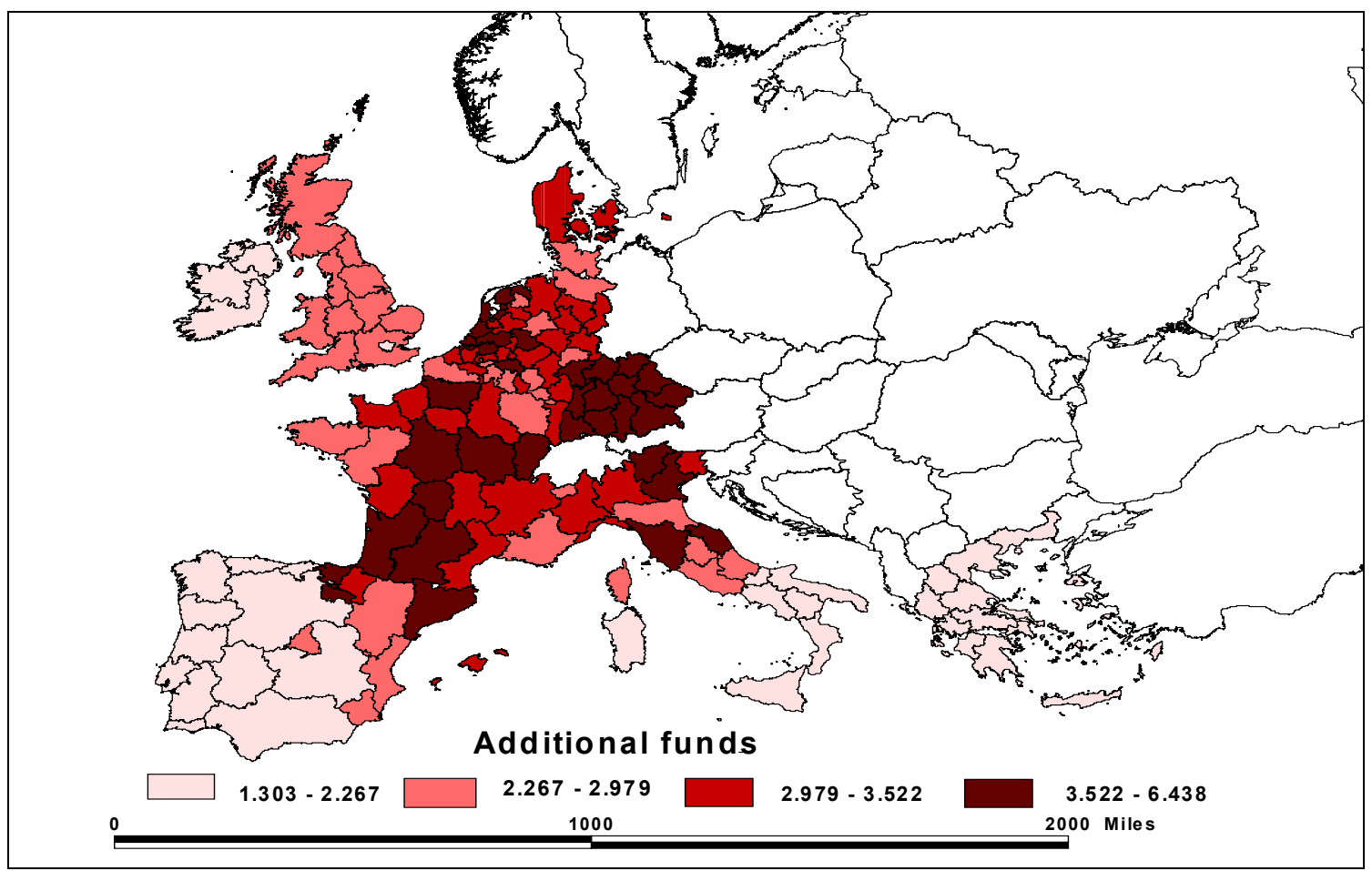

Figure 3: Additional funds: total costs/structural funds over 1989-1999

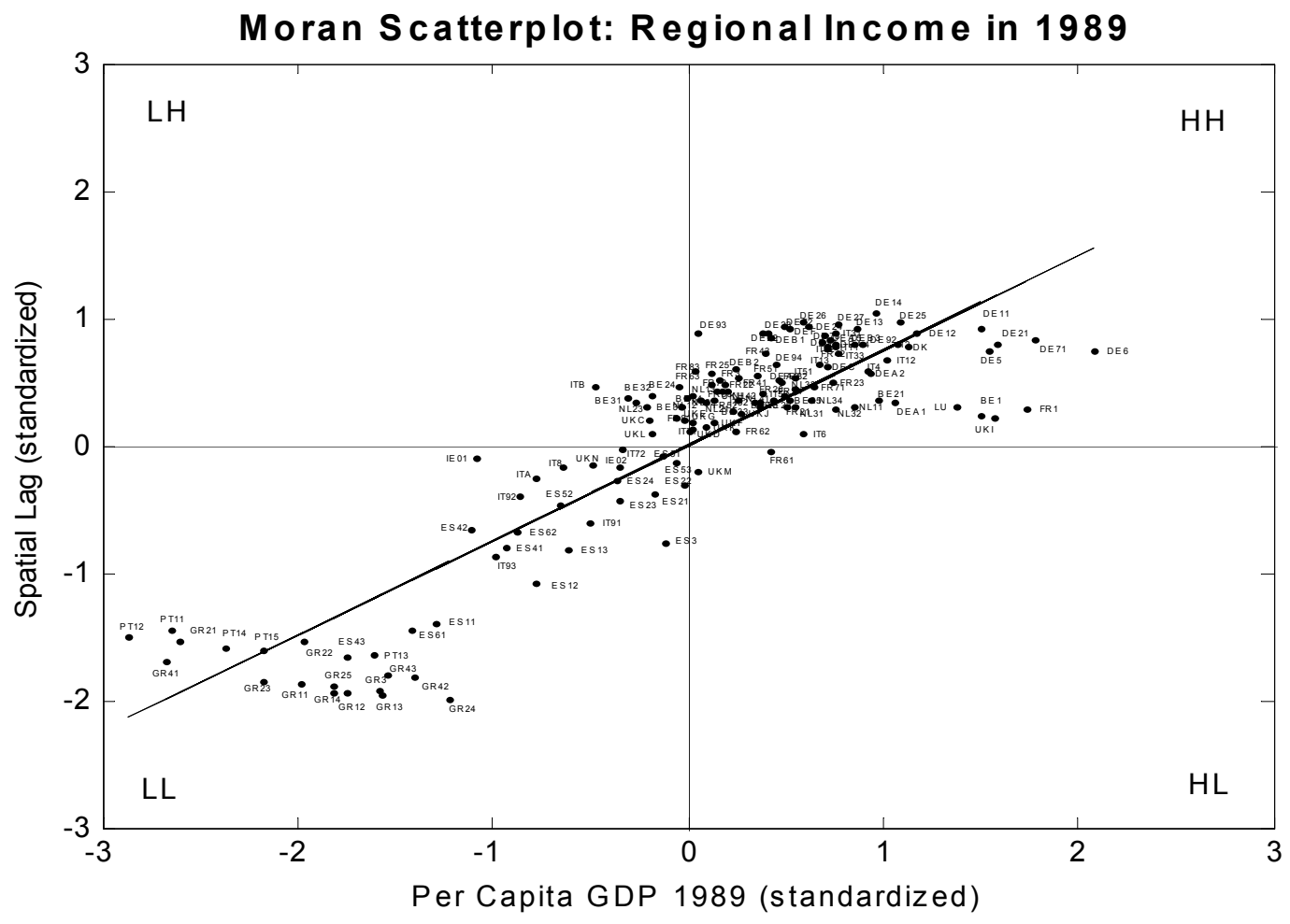

Figure 4: Moran scatterplot of regional per capita GDP in 1989

Note: See table 2 for the region's name corresponding to each code 


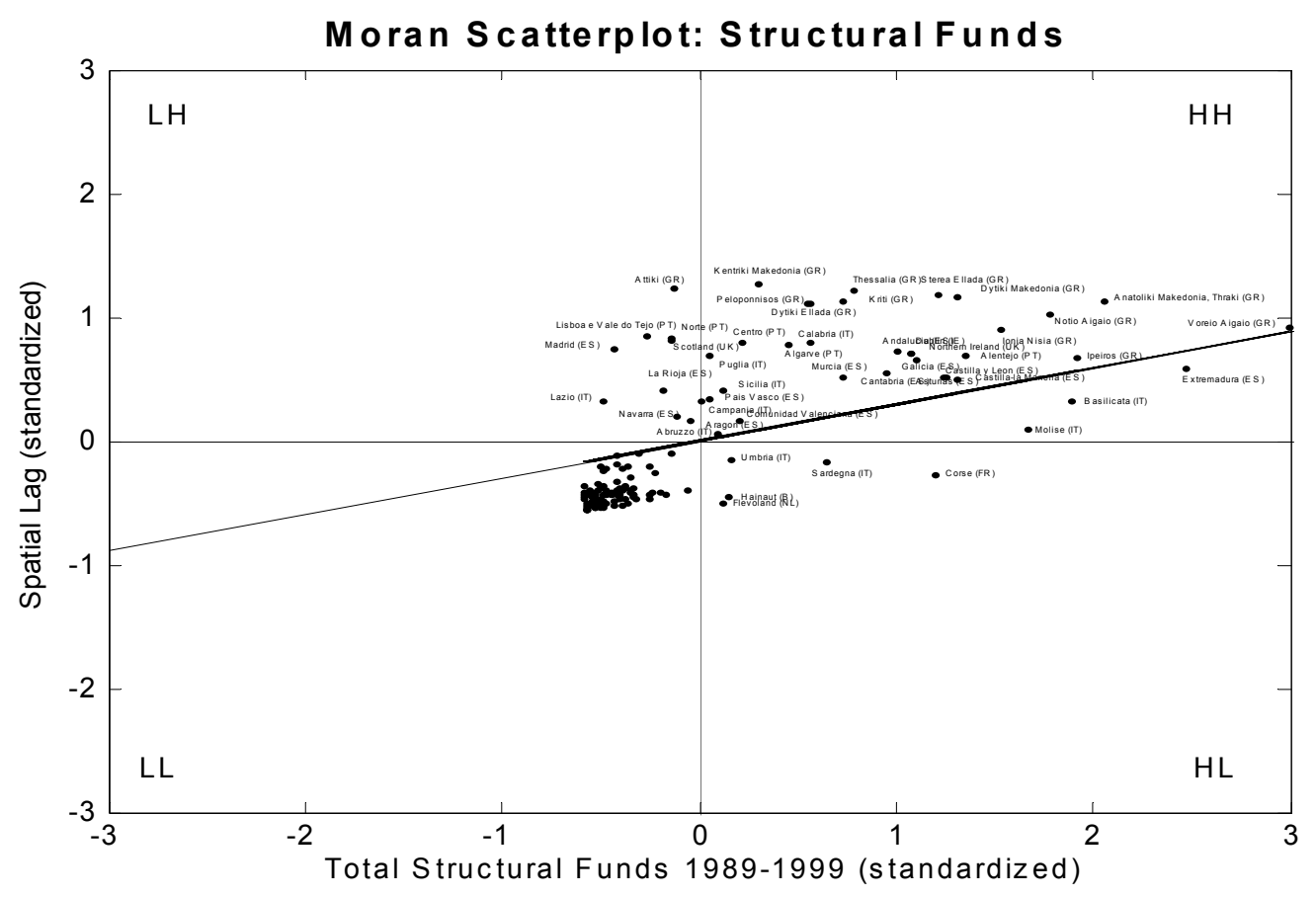

Figure 5: Moran scatterplot of total structural funds relative to region's average GDP Note 1: Out of the figure is the Irish region Border (HL-type) of which coordinates are $(8.252,-0.016)$ Note 2: The codes of the regions located in the LL-quadrant are not displayed for facilitating the reading (complete results are available in table 2)

Table 1: Moran's $I$ statistics and standard deviation

\begin{tabular}{|c|c|c|c|c|c|c|}
\hline & \multicolumn{2}{|c|}{10 neighbors } & \multicolumn{2}{c|}{ 15 neighbors } & \multicolumn{2}{c|}{ 20 neighbors } \\
\hline GDP 1989 & 0.7453 & $(0.0337)$ & 0.6787 & $(0.0265)$ & 0.5921 & $(0.0223)$ \\
\hline GDP 1990 & 0.7502 & $(0.0337)$ & 0.6828 & $(0.0265)$ & 0.5920 & $(0.0223)$ \\
\hline GDP 1991 & 0.7378 & $(0.0337)$ & 0.6706 & $(0.0265)$ & 0.5795 & $(0.0223)$ \\
\hline GDP 1992 & 0.7562 & $(0.0336)$ & 0.6932 & $(0.0265)$ & 0.6043 & $(0.0223)$ \\
\hline GDP 1993 & 0.7776 & $(0.0336)$ & 0.7308 & $(0.0265)$ & 0.6600 & $(0.0223)$ \\
\hline GDP 1994 & 0.7855 & $(0.0336)$ & 0.7429 & $(0.0265)$ & 0.6762 & $(0.0224)$ \\
\hline GDP 1995 & 0.7864 & $(0.0336)$ & 0.7502 & $(0.0266)$ & 0.6904 & $(0.0224)$ \\
\hline GDP 1996 & 0.7577 & $(0.0336)$ & 0.7180 & $(0.0266)$ & 0.6532 & $(0.0224)$ \\
\hline GDP 1997 & 0.7209 & $(0.0337)$ & 0.6868 & $(0.0265)$ & 0.6251 & $(0.0224)$ \\
\hline GDP 1998 & 0.7166 & $(0.0337)$ & 0.6815 & $(0.0265)$ & 0.6188 & $(0.0224)$ \\
\hline GDP 1999 & 0.6984 & $(0.0336)$ & 0.6654 & $(0.0265)$ & 0.6054 & $(0.0224)$ \\
\hline FS/M & 0.2932 & $(0.0294)$ & 0.2785 & $(0.0236)$ & 0.2529 & $(0.0198)$ \\
\hline CT/M & 0.1995 & $(0.0271)$ & 0.1836 & $(0.0217)$ & 0.1722 & $(0.0182)$ \\
\hline GROWTH & 0.4411 & $(0.0335)$ & 0.3454 & $(0.0267)$ & 0.2387 & $(0.0225)$ \\
\hline
\end{tabular}

Note: Standard deviations are into brackets. All statistics are significant at $p=0.0001$. Computations are based on 10000 random permutations. FS/M is total structural funds 89-99 over region's GDP average in 1989-1999; CT/M is Community projects total costs 89-99 over region's GDP average in 1989-1999. 
Table 2: Local spatial autocorrelation

\begin{tabular}{|c|c|c|c|c|c|c|c|c|c|c|c|c|}
\hline Code & Region & $\begin{array}{l}\text { Not } \\
\text { sign }\end{array}$ & HH & $\mathbf{L L}$ & HL & LH & $\begin{array}{c}\text { Bonf. } \\
5 \%\end{array}$ & $\begin{array}{l}\text { growth } \\
89-99\end{array}$ & Regions & fs $/ \mathbf{m}$ & ct $/ \mathbf{m}$ & $\mathbf{c t} / \mathbf{f s}$ \\
\hline & Belgium & & & & & & & & Belgium & & & \\
\hline BE1 & Brussels & 11 & 0 & 0 & 0 & 0 & 0 & ns & Brussels & LL & $\mathrm{LL}$ & $\mathrm{LH}^{*}$ \\
\hline BE21 & Antwerpen & 4 & 7 & 0 & 0 & 0 & 0 & $\mathrm{~ns}$ & Antwerpen & LL & $\mathrm{LL}$ & $\mathrm{HH}^{*}$ \\
\hline BE22 & Limburg & 5 & 6 & 0 & 0 & 0 & 0 & ns & Limburg & LL & LL & $\mathrm{HH}^{*}$ \\
\hline BE23 & $\begin{array}{c}\text { Oost- } \\
\text { Vlaanderen }\end{array}$ & 8 & 3 & 0 & 0 & 0 & 0 & ns & Oost-Vlaanderen & LL & LL & $\mathrm{HH}^{*}$ \\
\hline BE24 & Vlaams Brabant & 5 & 6 & 0 & 0 & 0 & 0 & $\mathrm{~ns}$ & Vlaams Brabant & LL & LL & $\mathrm{HH}^{*}$ \\
\hline BE25 & $\begin{array}{c}\text { West- } \\
\text { Vlaanderen }\end{array}$ & 8 & 3 & 0 & 0 & 0 & 0 & ns & West-Vlaanderen & LL & LL & $\mathrm{HH}^{*}$ \\
\hline BE31 & Brabant Wallon & 5 & 5 & 0 & 0 & 1 & 0 & ns & Brabant Wallon & LL & LL & $\mathrm{LH}^{*}$ \\
\hline BE32 & Hainaut & 8 & 0 & 0 & 0 & 3 & 0 & ns & Hainaut & $\mathrm{HL}$ & $\mathrm{HL}$ & $\mathrm{HH}^{*}$ \\
\hline BE33 & Liège & 7 & 4 & 0 & 0 & 0 & 0 & $\mathrm{~ns}$ & Liège & $\mathrm{LL}$ & $\mathrm{LL}$ & $\mathrm{HH}^{*}$ \\
\hline BE34 & Luxembourg & 4 & 7 & 0 & 0 & 0 & 0 & $\mathrm{~ns}$ & Luxembourg & $\mathrm{LL}$ & $\mathrm{LL}$ & $\mathrm{LH}^{*}$ \\
\hline \multirow[t]{2}{*}{ BE35 } & Namur & 8 & 1 & 0 & 0 & 2 & 0 & ns & Namur & LL & $\mathrm{LL}^{*}$ & $\mathrm{LH}^{*}$ \\
\hline & Germany & & & & & & & & Germany & & & \\
\hline DE11 & Stuttgart & 0 & 11 & 0 & 0 & 0 & 11 & ns & Stuttgart & LL & LL & $\mathrm{HH}$ \\
\hline DE12 & Karlsruhe & 0 & 11 & 0 & 0 & 0 & 11 & LL & Karlsruhe & $\mathrm{LL}$ & $\mathrm{LL}$ & $\mathrm{HH}$ \\
\hline DE13 & Freiburg & 0 & 11 & 0 & 0 & 0 & 11 & LL & Freiburg & $\mathrm{LL}$ & $\mathrm{LL}$ & $\mathrm{HH}$ \\
\hline DE14 & Tübingen & 0 & 11 & 0 & 0 & 0 & 11 & LL & Tübingen & LL & $\mathrm{LL}$ & $\mathrm{HH}$ \\
\hline DE21 & Oberbayern & 0 & 11 & 0 & 0 & 0 & 11 & $\mathrm{~ns}$ & Oberbayern & LL & LL & $\mathrm{HH}$ \\
\hline DE22 & Niederbayern & 0 & 11 & 0 & 0 & 0 & 11 & ns & Niederbayern & $\mathrm{LL}$ & $\mathrm{LL}$ & $\mathrm{HH}$ \\
\hline DE23 & Oberpfalz & 0 & 11 & 0 & 0 & 0 & 11 & $\mathrm{~ns}$ & Oberpfalz & $\mathrm{LL}$ & $\mathrm{LL}$ & $\mathrm{HH}$ \\
\hline DE24 & Oberfranken & 0 & 11 & 0 & 0 & 0 & 11 & ns & Oberfranken & $\mathrm{LL}$ & $\mathrm{LL}$ & $\mathrm{HH}$ \\
\hline DE25 & Mittelfranken & 0 & 11 & 0 & 0 & 0 & 11 & ns & Mittelfranken & LL & LL & $\mathrm{HH}$ \\
\hline DE26 & Unterfranken & 0 & 11 & 0 & 0 & 0 & 11 & ns & Unterfranken & LL & $\mathrm{LL}$ & $\mathrm{HH}$ \\
\hline DE27 & Schwaben & 0 & 11 & 0 & 0 & 0 & 11 & $\mathrm{~ns}$ & Schwaben & LL & $\mathrm{LL}$ & $\mathrm{HH}$ \\
\hline DE5 & Bremen & 0 & 11 & 0 & 0 & 0 & 11 & $\mathrm{~ns}$ & Bremen & $\mathrm{LL}$ & $\mathrm{LL}$ & $\mathrm{HH}^{*}$ \\
\hline DE6 & Hamburg & 0 & 11 & 0 & 0 & 0 & 11 & $\mathrm{~ns}$ & Hamburg & $\mathrm{LL}$ & $\mathrm{LL}$ & $\mathrm{LH}^{*}$ \\
\hline DE71 & Darmstadt & 0 & 11 & 0 & 0 & 0 & 11 & LL & Darmstadt & $L L$ & $L L$ & $\mathrm{HH}$ \\
\hline DE72 & Gießen & 0 & 11 & 0 & 0 & 0 & 11 & $\mathrm{HL}$ & Gießen & LL & $\mathrm{LL}$ & $\mathrm{LH}$ \\
\hline DE73 & Kassel & 0 & 11 & 0 & 0 & 0 & 11 & $\mathrm{HL}$ & Kassel & LL & $\mathrm{LL}$ & $\mathrm{HH}$ \\
\hline DE91 & Braunschweig & 0 & 11 & 0 & 0 & 0 & 11 & ns & Braunschweig & LL & LL & $\mathrm{HH}^{*}$ \\
\hline DE92 & Hannover & 0 & 11 & 0 & 0 & 0 & 11 & ns & Hannover & $\overline{L L}$ & $\overline{L L}$ & $\mathrm{HL}^{*}$ \\
\hline DE93 & Lüneburg & 0 & 8 & 0 & 0 & 3 & 11 & $\mathrm{~ns}$ & Lüneburg & $\mathrm{LL}$ & $\mathrm{LL}$ & $\mathrm{LL}^{*}$ \\
\hline DE94 & Weser-Ems & 0 & 11 & 0 & 0 & 0 & 4 & ns & Weser-Ems & LL & $\mathrm{LL}$ & $\mathrm{HH}^{*}$ \\
\hline DEA1 & Düsseldorf & 9 & 2 & 0 & 0 & 0 & 1 & ns & Düsseldorf & LL & LL & $\mathrm{HH}^{*}$ \\
\hline DEA2 & Köln & 0 & 11 & 0 & 0 & 0 & 2 & ns & Köln & LL & $\mathrm{LL}$ & $\mathrm{HH}^{\star}$ \\
\hline DEA3 & Münster & 0 & 11 & 0 & 0 & 0 & 0 & ns & Münster & LL & $\mathrm{LL}$ & $\mathrm{LH}^{*}$ \\
\hline DEA4 & Detmold & 0 & 11 & 0 & 0 & 0 & 11 & ns & Detmold & LL & $\mathrm{LL}$ & $\mathrm{HL}^{*}$ \\
\hline DEA5 & Arnsberg & 0 & 11 & 0 & 0 & 0 & 11 & LL & Arnsberg & LL & $\mathrm{LL}$ & $\mathrm{HH}^{*}$ \\
\hline DEB1 & Koblenz & 0 & 11 & 0 & 0 & 0 & 11 & ns & Koblenz & LL & LL & $\mathrm{HH}^{*}$ \\
\hline DEB2 & Trier & 0 & 9 & 0 & 0 & 2 & 2 & ns & Trier & $\mathrm{LL}$ & $\mathrm{LL}$ & $\mathrm{LH}^{*}$ \\
\hline DEB3 & $\begin{array}{l}\text { Rheinhessen- } \\
\text { Pfalz }\end{array}$ & 0 & 11 & 0 & 0 & 0 & 11 & LL & $\begin{array}{l}\text { Rheinhessen- } \\
\text { Pfalz }\end{array}$ & LL & LL & $\mathrm{HH}$ \\
\hline DEC & Saarland & 0 & 11 & 0 & 0 & 0 & 3 & $\mathrm{~ns}$ & Saarland & $\mathrm{LL}$ & $\mathrm{LL}$ & $\mathrm{LH}$ \\
\hline DEF & $\begin{array}{l}\text { Schleswig- } \\
\text { Holstein }\end{array}$ & 0 & 11 & 0 & 0 & 0 & 11 & ns & $\begin{array}{l}\text { Schleswig- } \\
\text { Holstein }\end{array}$ & LL & LL & $\mathrm{LH}^{*}$ \\
\hline DK & Denmark & 0 & 11 & 0 & 0 & 0 & 11 & ns & Denmark & $\mathrm{LL}$ & $\mathrm{LL}$ & $\mathrm{HH}^{*}$ \\
\hline & Spain & & & & & & & & Spain & & & \\
\hline ES11 & Galicia & 0 & 0 & 11 & 0 & 0 & 11 & $\mathrm{LH}$ & Galicia & $\mathrm{HH}$ & $\mathrm{HH}^{*}$ & $\mathrm{LL}$ \\
\hline ES12 & Asturias & 0 & 0 & 11 & 0 & 0 & 11 & $\mathrm{~ns}$ & Asturias & $\mathrm{HH}^{*}$ & $\mathrm{HH}^{*}$ & $\mathrm{LL}$ \\
\hline ES13 & Cantabria & 2 & 0 & 9 & 0 & 0 & 0 & $\mathrm{~ns}$ & Cantabria & $\mathrm{HH}^{*}$ & $\mathrm{HH}^{*}$ & $\mathrm{LL}^{*}$ \\
\hline ES21 & Pais Vasco & 7 & 0 & 4 & 0 & 0 & 0 & ns & Pais Vasco & $\mathrm{HH}^{*}$ & $\mathrm{HH}^{*}$ & $\mathrm{HL}^{*}$ \\
\hline ES22 & Navarra & 10 & 0 & 1 & 0 & 0 & 0 & ns & Navarra & $\mathrm{LH}^{*}$ & $\mathrm{HH}^{*}$ & $\mathrm{HH}^{*}$ \\
\hline ES23 & La Rioja & 11 & 0 & 0 & 0 & 0 & 0 & ns & La Rioja & $\mathrm{LH}^{*}$ & $\mathrm{HH}^{*}$ & $\mathrm{HL}^{*}$ \\
\hline
\end{tabular}




\begin{tabular}{|c|c|c|c|c|c|c|c|c|c|c|c|c|}
\hline & Region & $\begin{array}{l}\text { Not } \\
\text { sign }\end{array}$ & HH & $\mathbf{L L}$ & HL & LH & $\begin{array}{l}\text { Bonf. } \\
\text { 5\% }\end{array}$ & $\begin{array}{l}\text { growth } \\
89-99\end{array}$ & Regions & fs $/ m$ & $\mathbf{c t} / \mathbf{m}$ & ct/fs \\
\hline ES24 & Aragón & 10 & 0 & 1 & 0 & 0 & 0 & ns & Aragón & $\mathrm{HH}^{*}$ & $\mathrm{HH}^{*}$ & $\mathrm{LH}^{*}$ \\
\hline ES3 & $\begin{array}{c}\text { Comunidad de } \\
\text { Madrid }\end{array}$ & 0 & 0 & 9 & 2 & 0 & 6 & ns & $\begin{array}{c}\text { Comunidad de } \\
\text { Madrid }\end{array}$ & $\mathrm{LH}$ & LH & $\mathrm{LL}^{*}$ \\
\hline ES41 & Castilla y León & 0 & 0 & 11 & 0 & 0 & 6 & ns & Castilla y León & $\mathrm{HH}^{*}$ & $\mathrm{HH}^{*}$ & $\mathrm{LL}^{*}$ \\
\hline ES42 & Castilla-la Manch & 0 & 0 & 11 & 0 & 0 & 5 & ns & Castilla-la Manch & $\mathrm{HH}^{*}$ & $\mathrm{HH}^{*}$ & $\mathrm{LL}^{*}$ \\
\hline ES43 & Extremadura & 0 & 0 & 11 & 0 & 0 & 11 & $\mathrm{HH}$ & Extremadura & $\mathrm{HH}^{*}$ & $\mathrm{HH}^{*}$ & $\mathrm{LL}$ \\
\hline ES51 & Cataluña & 11 & 0 & 0 & 0 & 0 & 0 & $\mathrm{~ns}$ & Cataluña & $\mathrm{LL}^{*}$ & $\mathrm{HH}^{*}$ & $\mathrm{HH}^{*}$ \\
\hline ES52 & $\begin{array}{l}\text { Comunidad } \\
\text { Valenciana } \\
\end{array}$ & 4 & 0 & 7 & 0 & 0 & 0 & ns & $\begin{array}{l}\text { Comunidad } \\
\text { Valenciana }\end{array}$ & $\mathrm{HH}^{*}$ & $\mathrm{HH}^{*}$ & $\mathrm{LH}^{*}$ \\
\hline ES53 & Baleares & 0 & 0 & 11 & 0 & 0 & 0 & LL & Baleares & $\mathrm{LL}^{*}$ & $\mathrm{LH}^{*}$ & $\mathrm{HH}^{*}$ \\
\hline ES61 & Andalucia & 0 & 0 & 11 & 0 & 0 & 11 & LH & Andalucia & $\mathrm{HH}$ & $\mathrm{HH}^{*}$ & $\mathrm{LL}$ \\
\hline ES62 & Murcia & 1 & 0 & 10 & 0 & 0 & 5 & $\mathrm{~ns}$ & Murcia & $\mathrm{HH}^{*}$ & $\mathrm{HH}^{*}$ & $\mathrm{LL}^{*}$ \\
\hline & France & & & & & & & & France & & & \\
\hline FR1 & Ile de France & 11 & 0 & 0 & 0 & 0 & 0 & $\mathrm{~ns}$ & Ile de France & $\mathrm{LL}^{*}$ & $\mathrm{LL}^{*}$ & $\mathrm{HH}^{*}$ \\
\hline FR21 & $\begin{array}{l}\text { Champagne- } \\
\text { Ardenne }\end{array}$ & 10 & 1 & 0 & 0 & 0 & 0 & ns & $\begin{array}{l}\text { Champagne- } \\
\text { Ardenne }\end{array}$ & $\mathrm{LL}^{*}$ & LL* $^{*}$ & $\mathrm{HH}^{*}$ \\
\hline FR22 & Picardie & 3 & 5 & 0 & 0 & 3 & 0 & ns & Picardie & $\mathrm{LL}$ & $\mathrm{LL}^{*}$ & $\mathrm{HH}^{*}$ \\
\hline FR23 & Haute-Normandi & 8 & 3 & 0 & 0 & 0 & 0 & ns & Haute-Normandi & $\mathrm{LL}$ & $\mathrm{LL}^{*}$ & $\mathrm{HH}^{*}$ \\
\hline FR24 & Centre & 11 & 0 & 0 & 0 & 0 & 0 & $\overline{\mathrm{LL}}$ & Centre & $\mathrm{LL}^{*}$ & $\mathrm{LL}^{*}$ & $\mathrm{HH}^{*}$ \\
\hline FR25 & Basse-Normandi & 6 & 5 & 0 & 0 & 0 & 0 & ns & Basse-Normandi & $\mathrm{LL}$ & $\mathrm{LL}$ & $\mathrm{HL}$ \\
\hline FR26 & Bourgogne & 11 & 0 & 0 & 0 & 0 & 0 & ns & Bourgogne & $\mathrm{LL}$ & $\mathrm{LL}$ & $\mathrm{HH}^{*}$ \\
\hline FR3 & $\begin{array}{c}\text { Nord - Pas- de- } \\
\text { Calais }\end{array}$ & 0 & 11 & 0 & 0 & 0 & 0 & ns & $\begin{array}{c}\text { Nord - Pas - de- } \\
\text { Calais }\end{array}$ & LL & $\mathrm{LL}^{*}$ & $\mathrm{LH}^{*}$ \\
\hline FR41 & Lorraine & 1 & 10 & 0 & 0 & 0 & 0 & ns & Lorraine & $\mathrm{LL}$ & $\mathrm{LL}$ & $\mathrm{LH}^{*}$ \\
\hline FR42 & Alsace & 0 & 11 & 0 & 0 & 0 & 7 & LL & Alsace & $\mathrm{LL}$ & $\mathrm{LL}$ & $\mathrm{HH}$ \\
\hline FR43 & Franche-Comté & 0 & 11 & 0 & 0 & 0 & 3 & LL & Franche-Comté & $\mathrm{LL}$ & $\mathrm{LL}$ & $\mathrm{HH}^{*}$ \\
\hline FR51 & Pays de la Loire & 6 & 5 & 0 & 0 & 0 & 0 & $\mathrm{~ns}$ & Pays de la Loire & LL & LL & $\mathrm{LH}^{*}$ \\
\hline FR52 & Bretagne & 11 & 0 & 0 & 0 & 0 & 0 & $\mathrm{~ns}$ & Bretagne & LL & LL & $\mathrm{LL}^{*}$ \\
\hline FR53 & $\begin{array}{c}\text { Poitou- } \\
\text { Charentes }\end{array}$ & 11 & 0 & 0 & 0 & 0 & 0 & LL & Poitou-Charentes & LL & $L^{*}$ & $\mathrm{HH}^{*}$ \\
\hline FR61 & Aquitaine & 11 & 0 & 0 & 0 & 0 & 0 & ns & Aquitaine & $\mathrm{LL}^{*}$ & $\mathrm{LH}^{*}$ & $\mathrm{HH}$ \\
\hline FR62 & Midi-Pyrénées & 11 & 0 & 0 & 0 & 0 & 0 & LL & Midi-Pyrénées & $\mathrm{LL}^{*}$ & $\mathrm{LL}^{*}$ & $\mathrm{HH}$ \\
\hline FR63 & Limousin & 11 & 0 & 0 & 0 & 0 & 0 & LL & Limousin & LL & $\mathrm{HL}^{*}$ & $\mathrm{HH}^{*}$ \\
\hline FR71 & Rhône-Alpes & 11 & 0 & 0 & 0 & 0 & 0 & LL & Rhône-Alpes & $\mathrm{LL}^{*}$ & $\mathrm{LL}^{*}$ & $\mathrm{HH}^{*}$ \\
\hline FR72 & Auvergne & 11 & 0 & 0 & 0 & 0 & 0 & LL & Auvergne & $\mathrm{LL}$ & $\mathrm{LL}^{*}$ & $\mathrm{HH}^{*}$ \\
\hline FR81 & $\begin{array}{c}\text { Languedoc- } \\
\text { Roussillon } \\
\end{array}$ & 11 & 0 & 0 & 0 & 0 & 0 & LL & $\begin{array}{c}\text { Languedoc- } \\
\text { Roussillon }\end{array}$ & $\mathrm{LL}^{*}$ & $\mathrm{LL}^{*}$ & $\mathrm{HH}$ \\
\hline FR82 & $\begin{array}{c}\text { Provence-Alpes- } \\
\text { Côte d'Azur } \\
\end{array}$ & 10 & 1 & 0 & 0 & 0 & 0 & LL & $\begin{array}{c}\text { Provence-Alpes- } \\
\text { Côte d'Azur } \\
\end{array}$ & $\mathrm{LL}^{*}$ & $\mathrm{LL}^{*}$ & $\mathrm{LH}^{*}$ \\
\hline FR83 & Corse & 0 & 1 & 0 & 0 & 10 & 0 & $\mathrm{HL}$ & Corse & $\mathrm{HL}^{*}$ & $\mathrm{HL}^{*}$ & $\mathrm{LL}^{*}$ \\
\hline & Greece & & & & & & & & Greece & & & \\
\hline GR11 & $\begin{array}{c}\text { Anatoliki } \\
\text { Makedonia, } \\
\text { Thraki }\end{array}$ & 0 & 0 & 11 & 0 & 0 & 11 & $\mathrm{HH}$ & $\begin{array}{c}\text { Anatoliki } \\
\text { Makedonia, } \\
\text { Thraki }\end{array}$ & $\mathrm{HH}$ & $\mathrm{HH}^{*}$ & LL \\
\hline GR12 & $\begin{array}{c}\text { Kentriki } \\
\text { Makedonia }\end{array}$ & 0 & 0 & 11 & 0 & 0 & 11 & $\mathrm{HH}$ & $\begin{array}{c}\text { Kentriki } \\
\text { Makedonia }\end{array}$ & $\mathrm{HH}$ & $\mathrm{HH}$ & LL \\
\hline GR13 & $\begin{array}{c}\text { Dytiki } \\
\text { Makedonia }\end{array}$ & 0 & 0 & 11 & 0 & 0 & 11 & $\mathrm{HH}$ & $\begin{array}{c}\text { Dytiki } \\
\text { Makedonia }\end{array}$ & $\mathrm{HH}$ & $\mathrm{HH}$ & LL \\
\hline GR14 & Thessalia & 0 & 0 & 11 & 0 & 0 & 11 & $\mathrm{HH}$ & Thessalia & $\mathrm{HH}$ & $\mathrm{HH}$ & $\mathrm{LL}$ \\
\hline GR21 & Ipeiros & 0 & 0 & 11 & 0 & 0 & 11 & $\mathrm{~ns}$ & Ipeiros & $\mathrm{HH}$ & $\mathrm{HH}^{*}$ & $\mathrm{LL}$ \\
\hline GR22 & Ionia Nisia & 0 & 0 & 11 & 0 & 0 & 11 & $\mathrm{~ns}$ & Ionia Nisia & $\mathrm{HH}$ & $\mathrm{HH}^{*}$ & LL \\
\hline GR23 & Dytiki Ellada & 0 & 0 & 11 & 0 & 0 & 11 & $\mathrm{HH}$ & Dytiki Ellada & $\mathrm{HH}$ & $\mathrm{HH}^{*}$ & $\mathrm{LL}$ \\
\hline GR24 & Sterea Ellada & 0 & 0 & 11 & 0 & 0 & 11 & LH & Sterea Ellada & $\mathrm{HH}$ & $\mathrm{HH}^{*}$ & $\mathrm{LL}$ \\
\hline GR25 & Peloponnisos & 0 & 0 & 11 & 0 & 0 & 11 & $\mathrm{HH}$ & Peloponnisos & $\mathrm{HH}$ & $\mathrm{HH}^{*}$ & $\mathrm{LL}$ \\
\hline GR3 & Attiki & 0 & 0 & 11 & 0 & 0 & 11 & ns & Attiki & LH & LH & $\mathrm{LL}$ \\
\hline GR41 & Voreio Aigaio & 0 & 0 & 11 & 0 & 0 & 11 & $\mathrm{HH}$ & Voreio Aigaio & $\mathrm{HH}$ & $\mathrm{HH}^{*}$ & LL \\
\hline
\end{tabular}




\begin{tabular}{|c|c|c|c|c|c|c|c|c|c|c|c|c|}
\hline & Region & $\begin{array}{l}\text { Not } \\
\text { sign }\end{array}$ & HH & $\mathbf{L L}$ & HL & LH & $\begin{array}{l}\text { Bonf. } \\
5 \%\end{array}$ & $\begin{array}{c}\text { growth } \\
89-99\end{array}$ & Regions & $\mathbf{f s} / \mathbf{m}$ & ct $/ \mathbf{m}$ & et $/ \mathbf{f s}$ \\
\hline GR42 & Notio Aigaio & 0 & 0 & 11 & 0 & 0 & 11 & $\mathrm{HH}$ & Notio Aigaio & $\mathrm{HH}$ & $\mathrm{HH}^{*}$ & $\mathrm{LL}$ \\
\hline \multirow{2}{*}{ GR43 } & Kriti & 0 & 0 & 11 & 0 & 0 & 11 & $\mathrm{HH}$ & Kriti & $\mathrm{HH}$ & $\mathrm{HH}^{*}$ & $\mathrm{LL}$ \\
\hline & Ireland & & & & & & & & Ireland & & & \\
\hline IE01 & Border & 11 & 0 & 0 & 0 & 0 & 0 & $\mathrm{HH}$ & Border & $\mathrm{HH}^{*}$ & $\mathrm{HH}^{*}$ & $\mathrm{LL}^{*}$ \\
\hline \multirow{2}{*}{$\mathrm{IE} 02$} & Dublin & 11 & 0 & 0 & 0 & 0 & 0 & $\mathrm{HH}$ & Dublin & $\mathrm{HH}$ & $\mathrm{HH}$ & $\mathrm{LL}^{*}$ \\
\hline & Italy & & & & & & & & Italy & & & \\
\hline IT11 & Piemonte & 0 & 11 & 0 & 0 & 0 & 4 & LL & Piemonte & LL & LL & $\mathrm{HH}$ \\
\hline IT12 & Valle d'Aosta & 1 & 10 & 0 & 0 & 0 & 0 & LL & Valle d'Aosta & $\mathrm{LL}$ & LL & $\mathrm{LH}$ \\
\hline IT13 & Liguria & 7 & 4 & 0 & 0 & 0 & 0 & LL & Liguria & $\mathrm{LL}^{*}$ & $\mathrm{LH}^{*}$ & $\mathrm{HH}^{*}$ \\
\hline IT2 & Lombardia & 1 & 10 & 0 & 0 & 0 & 4 & LL & Lombardia & $\mathrm{LL}$ & $\mathrm{LL}$ & $\mathrm{HH}$ \\
\hline IT31 & $\begin{array}{l}\text { Trentino-Alto } \\
\text { Adige }\end{array}$ & 0 & 11 & 0 & 0 & 0 & 10 & LL & $\begin{array}{l}\text { Trentino-Alto } \\
\text { Adige }\end{array}$ & LL & LL & $\mathrm{HH}$ \\
\hline IT32 & Veneto & 1 & 10 & 0 & 0 & 0 & 4 & LL & Veneto & LL & $\mathrm{LL}^{*}$ & $\mathrm{HH}$ \\
\hline IT33 & $\begin{array}{c}\text { Friuli-Venezia } \\
\text { Giulia }\end{array}$ & 0 & 11 & 0 & 0 & 0 & 4 & LL & $\begin{array}{c}\text { Friuli-Venezia } \\
\text { Giulia }\end{array}$ & LL & $L^{*}$ & $\mathrm{HH}$ \\
\hline IT4 & $\begin{array}{c}\text { Emilia- } \\
\text { Romagna }\end{array}$ & 7 & 4 & 0 & 0 & 0 & 0 & LL & Emilia-Romagna & $\mathrm{LL}^{*}$ & $\mathrm{LL}^{*}$ & $\mathrm{LH}^{*}$ \\
\hline IT51 & Toscana & 7 & 4 & 0 & 0 & 0 & 0 & LL & Toscana & $\mathrm{LL}^{*}$ & $\mathrm{LH}^{*}$ & $\mathrm{HH}^{*}$ \\
\hline IT52 & Umbria & 11 & 0 & 0 & 0 & 0 & 0 & $\overline{\mathrm{LL}}$ & Umbria & $\mathrm{HL}^{*}$ & $\mathrm{HL}^{*}$ & $\mathrm{LL}^{*}$ \\
\hline IT53 & Marche & 11 & 0 & 0 & 0 & 0 & 0 & LL & Marche & $\mathrm{LL}^{*}$ & $\mathrm{LH}^{*}$ & $\mathrm{HL}^{*}$ \\
\hline IT6 & Lazio & 11 & 0 & 0 & 0 & 0 & 0 & LL & Lazio & $\mathrm{LH}^{*}$ & $\mathrm{LH}^{*}$ & $\mathrm{LL}^{*}$ \\
\hline IT71 & Abruzzo & 11 & 0 & 0 & 0 & 0 & 0 & LL & Abruzzo & $\mathrm{LH}^{*}$ & $\mathrm{HH}^{*}$ & $\mathrm{LL}^{*}$ \\
\hline IT72 & Molise & 10 & 0 & 1 & 0 & 0 & 0 & LL & Molise & $\mathrm{HH}^{*}$ & $\mathrm{HH}^{*}$ & $\mathrm{LL}^{*}$ \\
\hline IT8 & Campania & 6 & 0 & 5 & 0 & 0 & 0 & LL & Campania & $\mathrm{HH}^{*}$ & $\mathrm{LH}^{*}$ & $\mathrm{LL}^{*}$ \\
\hline IT91 & Puglia & 0 & 0 & 11 & 0 & 0 & 6 & ns & Puglia & $\mathrm{HH}$ & $\mathrm{HH}^{*}$ & $\mathrm{LL}$ \\
\hline IT92 & Basilicata & 4 & 0 & 7 & 0 & 0 & 1 & LL & Basilicata & $\mathrm{HH}^{*}$ & $\mathrm{HH}^{*}$ & LL \\
\hline IT93 & Calabria & 0 & 0 & 11 & 0 & 0 & 10 & $\mathrm{~ns}$ & Calabria & $\mathrm{HH}$ & $\mathrm{HH}^{*}$ & $\mathrm{LL}$ \\
\hline ITA & Sicilia & 4 & 0 & 7 & 0 & 0 & 1 & LL & Sicilia & $\mathrm{HH}^{*}$ & $\mathrm{HH}^{*}$ & $\mathrm{LL}$ \\
\hline ITB & Sardegna & 10 & 0 & 0 & 0 & 1 & 0 & LL & Sardegna & $\mathrm{HL}^{*}$ & $\mathrm{HH}^{*}$ & $\mathrm{LL}^{*}$ \\
\hline \multirow[t]{2}{*}{ LU } & Luxembourg & 10 & 1 & 0 & 0 & 0 & 0 & LL & Luxembourg & $\mathrm{LL}$ & $\mathrm{LL}$ & $\mathrm{HL}^{*}$ \\
\hline & Netherlands & & & & & & & & Netherlands & & & \\
\hline $\mathrm{NL} 11$ & Groningen & 10 & 1 & 0 & 0 & 0 & 0 & ns & Groningen & LL & $\mathrm{LL}^{*}$ & $\mathrm{HH}$ \\
\hline NL12 & Friesland & 10 & 1 & 0 & 0 & 0 & 0 & $\mathrm{~ns}$ & Friesland & LL & $\mathrm{LL}^{*}$ & $\mathrm{HH}$ \\
\hline NL13 & Drenthe & 7 & 4 & 0 & 0 & 0 & 0 & ns & Drenthe & LL & $L^{*}$ & LH \\
\hline NL21 & Overijssel & 9 & 2 & 0 & 0 & 0 & 0 & ns & Overijssel & LL & $\mathrm{LL}^{*}$ & $\mathrm{HH}$ \\
\hline NL22 & Gelderland & 10 & 1 & 0 & 0 & 0 & 0 & $\mathrm{~ns}$ & Gelderland & LL & $\mathrm{LL}^{*}$ & $\mathrm{HH}$ \\
\hline NL23 & Flevoland & 9 & 0 & 0 & 0 & 2 & 0 & ns & Flevoland & $\mathrm{HL}$ & $\mathrm{HL}$ & $\mathrm{HH}$ \\
\hline NL31 & Utrecht & 10 & 1 & 0 & 0 & 0 & 0 & ns & Utrecht & LL & $\mathrm{LL}^{*}$ & $\mathrm{HH}$ \\
\hline NL32 & Noord-Holland & 11 & 0 & 0 & 0 & 0 & 0 & ns & Noord-Holland & LL & $\mathrm{LL}^{*}$ & $\mathrm{HH}$ \\
\hline NL33 & Zuid-Holland & 4 & 7 & 0 & 0 & 0 & 0 & ns & Zuid-Holland & LL & LL & $\mathrm{HH}$ \\
\hline NL34 & Zeeland & 4 & 7 & 0 & 0 & 0 & 0 & $\mathrm{~ns}$ & Zeeland & $\overline{\mathrm{LL}}$ & $\mathrm{LL}$ & $\mathrm{HH}^{*}$ \\
\hline NL41 & Noord-Brabant & 5 & 6 & 0 & 0 & 0 & 0 & ns & Noord-Brabant & $\mathrm{LL}$ & $\mathrm{LL}^{*}$ & $\mathrm{HH}$ \\
\hline \multirow[t]{2}{*}{ NL42 } & Limburg & 4 & 7 & 0 & 0 & 0 & 0 & ns & Limburg & LL & $\mathrm{LL}^{*}$ & $\mathrm{HH}$ \\
\hline & Portugal & & & & & & & & Portugal & & & \\
\hline PT11 & Norte & 0 & 0 & 11 & 0 & 0 & 11 & $\mathrm{HH}$ & Norte & $\mathrm{LH}$ & $\mathrm{LH}^{*}$ & $\mathrm{LL}$ \\
\hline PT12 & Centro & 0 & 0 & 11 & 0 & 0 & 11 & $\mathrm{HH}$ & Centro & $\mathrm{HH}$ & $\mathrm{LH}^{*}$ & $\mathrm{LL}$ \\
\hline PT13 & $\begin{array}{c}\text { Lisboa e Vale do } \\
\text { Tejo }\end{array}$ & 0 & 0 & 11 & 0 & 0 & 11 & $\mathrm{HH}$ & $\begin{array}{c}\text { Lisboa e Vale do } \\
\text { Tejo }\end{array}$ & $\mathrm{LH}$ & $\mathrm{LH}^{*}$ & LL \\
\hline PT14 & Alentejo & 0 & 0 & 11 & 0 & 0 & 11 & $\mathrm{HH}$ & Alentejo & $\mathrm{HH}$ & $\mathrm{HH}^{*}$ & LL \\
\hline \multirow[t]{2}{*}{ PT15 } & Algarve & 0 & 0 & 11 & 0 & 0 & 11 & $\mathrm{HH}$ & \begin{tabular}{c|} 
Algarve \\
\end{tabular} & $\mathrm{HH}$ & $\mathrm{HH}^{*}$ & LL \\
\hline & United-Kingdor & & & & & & & & United-Kingdon & & & \\
\hline UKC & North East & 11 & 0 & 0 & 0 & 0 & 0 & $\mathrm{HH}$ & North East & LL & $\mathrm{HL}$ & $\mathrm{LL}^{*}$ \\
\hline UKK & South West & 11 & 0 & 0 & 0 & 0 & 0 & ns & South West & $\mathrm{LL}^{*}$ & $\mathrm{LL}^{*}$ & $\mathrm{LL}^{*}$ \\
\hline UKL & Wales & 11 & 0 & 0 & 0 & 0 & 0 & $\mathrm{HH}$ & Wales & $\mathrm{LL}^{*}$ & $\mathrm{LH}^{*}$ & $\mathrm{LL}$ \\
\hline UKM & Scotland & 11 & 0 & 0 & 0 & 0 & 0 & $\mathrm{HH}$ & Scotland & $\mathrm{LH}$ & $\mathrm{LH}$ & LL \\
\hline UKN & Northern Ireland & 11 & 0 & 0 & 0 & 0 & 0 & $\mathrm{HH}$ & Northern Ireland & $\mathrm{HH}$ & $\mathrm{HH}$ & $\mathrm{LL}^{*}$ \\
\hline
\end{tabular}




\begin{tabular}{|c|c|c|c|c|c|c|c|c|c|c|c|c|}
\hline & Region & $\begin{array}{l}\text { Not } \\
\text { sign }\end{array}$ & HH & $\mathbf{L L}$ & HL & LH & $\begin{array}{c}\text { Bonf. } \\
5 \%\end{array}$ & $\begin{array}{c}\text { growth } \\
89-99\end{array}$ & Regions & fs $/ \mathrm{m}$ & ct $/ \mathrm{m}$ & ct/fs \\
\hline UKD & North West & 11 & 0 & 0 & 0 & 0 & 0 & $\mathrm{HH}$ & North West & $\mathrm{LL}^{*}$ & $\mathrm{LL}^{*}$ & $\mathrm{HL}$ \\
\hline UKE & $\begin{array}{c}\text { Yorkshire and th } \\
\text { Humber }\end{array}$ & 11 & 0 & 0 & 0 & 0 & 0 & ns & $\begin{array}{c}\text { Yorkshire and th } \\
\text { Humber }\end{array}$ & $\mathrm{LL}^{*}$ & LL & $\mathrm{LL}^{*}$ \\
\hline UKF & East Midlands & 11 & 0 & 0 & 0 & 0 & 0 & $\mathrm{HH}$ & East Midlands & $\mathrm{LL}^{*}$ & $\mathrm{LL}^{*}$ & $\mathrm{LL}^{*}$ \\
\hline UKG & West Midlands & 11 & 0 & 0 & 0 & 0 & 0 & $\mathrm{~ns}$ & West Midlands & LL & $\mathrm{LL}$ & $\mathrm{LL}^{*}$ \\
\hline $\mathrm{UKH}$ & Eastern & 9 & 2 & 0 & 0 & 0 & 0 & ns & Eastern & LL & $\mathrm{LL}$ & $\mathrm{LL}^{*}$ \\
\hline UKI & London & 11 & 0 & 0 & 0 & 0 & 0 & ns & London & LL & LL & $\mathrm{LL}^{*}$ \\
\hline UKJ & South East & 11 & 0 & 0 & 0 & 0 & 0 & ns & South East & LL & LL & $\mathrm{LL}^{*}$ \\
\hline
\end{tabular}

Note: Level of pseudo-significance $p<0.05$. Not sign. denotes the number of years local statistics is not significant at 0.05 . Maximum number of years is 11 . $\mathbf{H H}$, number of years local statistics of significant and in quadrant HH of Moran's scatterplot; LL, number of years local statistics of significant and in quadrant LL of Moran's scatterplot; HL, number of years local statistics of significant and in quadrant HL of Moran's scatterplot; LH, number of years local statistics of significant and in quadrant LH of Moran's scatterplot. Bonf. $\mathbf{5 \%}$ indicates the number of years the statistics is significant at 5\% Bonferroni pseudo-significance level.

Growth 89-99 indicates if local statistics of growth rate over 1989-1999 is significant or not, if yes, then the quadrant in Moran's scatterplot it belongs to. ns means no significance at $p<0.05$. fs $/ \mathbf{m}$ is total structural funds 89-99 divided by the region's mean per capita GDP over 1989-1999; ct/m is Community projects total costs 8999 divided by the region's mean per capita GDP over 1989-1999; ct/fs is Community projects total costs divided by structural funds over 1989-1999, * indicates that the LISA statistics is not significant at the $5 \%$ pseudo-significance level.

Table 3: Robustness analysis for LISA from 10 to 15 neighbors

\begin{tabular}{|c|c|c|c|c|c|}
\hline K=10 K=15 & Not Sign. & HH & LL & HL & LH \\
\cline { 1 - 3 } Not Sign. & $67.8 \%$ & $21.9 \%$ & $4.6 \%$ & $0.1 \%$ & $5.6 \%$ \\
\cline { 1 - 3 } HH & $1.8 \%$ & $98.0 \%$ & $0 \%$ & $0 \%$ & $0.2 \%$ \\
\cline { 1 - 1 } LL & $6.2 \%$ & $0 \%$ & $93.8 \%$ & $0 \%$ & $0 \%$ \\
\cline { 1 - 1 } HL & $0 \%$ & $0 \%$ & $0 \%$ & $100 \%$ & $0 \%$ \\
\hline LH & $29.6 \%$ & $0 \%$ & $0 \%$ & $0 \%$ & $70.4 \%$ \\
\hline
\end{tabular}

Table 4: Robustness analysis for LISA from 10 to 20 neighbors

\begin{tabular}{|c|c|c|c|c|c|}
\hline $\mathrm{K}=10 \quad \mathrm{~K}=20$ & Not Sign. & $\mathrm{HH}$ & LL & HL & LH \\
\hline Not Sign. & $54.8 \%$ & $31.6 \%$ & $4.5 \%$ & $0 \%$ & $9.1 \%$ \\
\hline HH & $1.5 \%$ & $98.3 \%$ & $0 \%$ & $0 \%$ & $0.2 \%$ \\
\hline $\mathrm{LL}$ & $5.3 \%$ & $0 \%$ & $94.7 \%$ & $0 \%$ & $0 \%$ \\
\hline HL & $0 \%$ & $0 \%$ & $0 \%$ & $100 \%$ & $0 \%$ \\
\hline LH & $25.9 \%$ & $0 \%$ & $0 \%$ & $0 \%$ & $74.1 \%$ \\
\hline
\end{tabular}


Table 5: Correlation table of growth rate (1989-1999) by initial per capita GDP (1989)

\begin{tabular}{|c|c|c|c|c|c|c|}
\hline & \multicolumn{6}{|c|}{ Per capita GDP 1989} \\
\hline $\begin{array}{l}\text { Growth } \\
\text { rate }\end{array}$ & $\begin{array}{l}\text { Not } \\
\text { Sign. }\end{array}$ & $\mathrm{HH}$ & LL & HL & LH & Sum \\
\hline Not Sign. & 40 & 29 & 11 & 0 & 0 & 80 \\
\hline $\mathrm{HH}$ & 8 & 0 & $\begin{array}{l}\text { Extremadura (ES), Anatoliki Makedonia } \\
\text { (GR), Kentriki Makedonia (GR), Dytiki } \\
\text { Makedonia (GR), Thessalia (GR), Dytiki } \\
\text { Ellada (GR), Peloponnisos (GR), Voreio } \\
\text { Aigaio (GR), Notio Aigaio (GR) Kriti (GR) } \\
\text { PORTUGAL } \\
\end{array}$ & 0 & 0 & 23 \\
\hline LL & 17 & $\begin{array}{l}\text { Karlsruhe (DE), Freiburg (DE), Tübingen (DE), } \\
\text { Darmstadt (DE), Arnsberg (DE), Rheinhessen- } \\
\text { Pfalz (DE), Alsace (FR), Franche-Comté (FR), } \\
\text { Provence-Alpes-Côte d'Azur (FR), Piemonte (IT), } \\
\text { Valle d'Aosta (IT), Liguria (IT), Lombardia (IT), } \\
\text { Trentino-Alto Adige (IT), Veneto (IT), Friuli- } \\
\text { Venezia Giulia (IT), Emilia-Romagna (IT), } \\
\text { Toscana (IT) } \\
\end{array}$ & $\begin{array}{c}\text { Baleares (ES) } \\
1\end{array}$ & 0 & 0 & 36 \\
\hline $\mathrm{HL}$ & 0 & $\begin{array}{c}\text { Gießen (DE) Kassel (DE) } \\
\text { Coarse (FR) } \\
3\end{array}$ & 0 & 0 & 0 & 3 \\
\hline LH & 0 & 0 & $\begin{array}{c}\text { Galicia (ES) Andalucia (ES) } \\
\text { Sterea Ellada (GR) } \\
3\end{array}$ & 0 & 0 & 3 \\
\hline Sum & 65 & 50 & 30 & 0 & 0 & 145 \\
\hline
\end{tabular}

Table 6: Correlation table of growth rate by structural funds 1989-1999

\begin{tabular}{|c|c|c|c|c|c|c|}
\hline & \multicolumn{6}{|c|}{ Total structural funds $1989-1999$} \\
\hline $\begin{array}{l}\text { Growth } \\
\text { rate }\end{array}$ & $\begin{array}{l}\text { Not } \\
\text { Sign. }\end{array}$ & $\mathrm{HH}$ & LL & HL & LH & Sum \\
\hline Not Sign. & 16 & 4 & 56 & 2 & 2 & 80 \\
\hline $\mathrm{HH}$ & 5 & $\begin{array}{l}\text { Anatoliki Makedonia (GR), Kriti (GR), Kentriki } \\
\text { Makedonia (GR), Dytiki Makedonia (GR), } \\
\text { Thessalia (GR), Dytiki Ellada (GR), Peloponnisos } \\
\text { (GR), Voreio Aigaio (GR), Notio Aigaio (GR), } \\
\text { Dublin (IE), Centro (PT), Alentejo (PT), Algarve } \\
\text { (PT), Northern Ireland (UK) } \\
\text { 14 }\end{array}$ & $\begin{array}{c}\text { North East (UK) } \\
1\end{array}$ & 0 & $\begin{array}{l}\text { Norte (PT) } \\
\text { Lisboa e } \\
\text { Vale do } \\
\text { Tejo (PT) } \\
\text { Scotland } \\
\text { (UK) } \\
\text { (3) }\end{array}$ & 23 \\
\hline LL & 18 & 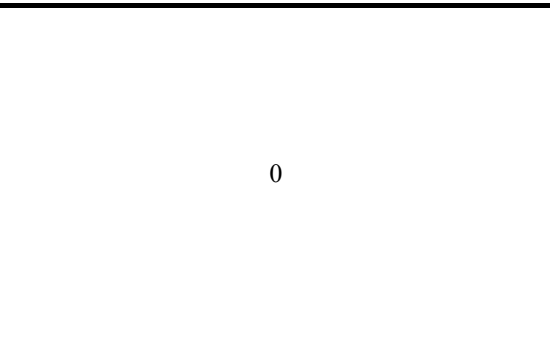 & $\begin{array}{l}\text { Karlsruhe } \text { (DE), Freiburg (DE), } \\
\text { Tübingen (DE), Darmstadt (DE), } \\
\text { Arnsberg (DE), Rheinhessen-Pfalz } \\
\text { (DE), Alsace (FR), Franche-Comté } \\
\text { (FR), Poitou-Charentes (FR), Limousin } \\
\text { (FR), Auvergne (FR), Piemonte (IT), } \\
\text { Veneto (IT), Valle d'Aosta (IT), } \\
\text { Lombardia (IT), Trentino-Alto Adige } \\
\text { (IT), Friuli-Venezia Giulia (IT) } \\
\text { LUXEMBOURG } \\
18\end{array}$ & 0 & 0 & 36 \\
\hline $\mathrm{HL}$ & 1 & 0 & Gießen (DE) Kassel (DE) & 0 & 0 & 3 \\
\hline LH & 0 & $\begin{array}{c}\text { Galicia (ES) Andalucia (ES) } \\
\text { Sterea Ellada (GR) } \\
3\end{array}$ & 0 & 0 & 0 & 3 \\
\hline Sum & 40 & 21 & 77 & 2 & 5 & 145 \\
\hline
\end{tabular}

